\title{
Making the Workplace 'Safe' in Capitalism: The Enforcement of Factory Legislation in Nineteenth Century Ontario
}

Eric Tucker

Osgoode Hall Law School of York University, etucker@osgoode.yorku.ca

Source Publication:

Labour/Le Travail. Volume 21 (1988), p. 45-86.

Follow this and additional works at: https://digitalcommons.osgoode.yorku.ca/scholarly_works cc) (1) $\Theta(9$

This work is licensed under a Creative Commons Attribution-Noncommercial-No Derivative Works 4.0 License.

\section{Recommended Citation}

Tucker, Eric. "Making the Workplace 'Safe' in Capitalism: The Enforcement of Factory Legislation in Nineteenth Century Ontario." Labour/Le Travail 21 (1988): 45-86.

This Article is brought to you for free and open access by the Faculty Scholarship at Osgoode Digital Commons. It has been accepted for inclusion in Articles \& Book Chapters by an authorized administrator of Osgoode Digital Commons. 


\title{
Making The Workplace 'Safe' In Capitalism:
}

\section{The Enforcement of Factory Legislation in Nineteenth- Century Ontario}

\author{
Eric Tucker
}

No ONE HAS EVER ATTEMPTED to estimate the total number of workers in Ontario who have been killed or injured, or whose health has been impaired, over the last 100 years as a result of their work. Even if a conservative estimate were produced, I have little doubt that most people would be shocked, and would find that the toll was unacceptably high.' In 1985 alone, over 426,880 claims were filed with the Ontario Workers' Compensation Board, ${ }^{2}$ and experts agree that Board figures underestimate the true significance of the problem. ${ }^{3}$

High levels of occupationally related death, injury, and disease have persisted over the last 100 years, notwithstanding that, throughout this period, the state has had the legal authority to impose health and safety standards on employers, and to implement those standards through a full-time inspectorate armed with substantial enforcement powers. The creation of this power and the failure to exercise it effectively raises some difficult questions about the role of the state in a capitalist social formation in general, and about the relations between labour and the state in particular. It is the purpose of

\footnotetext{
'Recent increases in the number of claims filed with the Workers' Compensation Board in Ontario caused William Wrye, then provincial Minister of Labour, to comment, "There is, to be frank, a distressing carnage in our workplaces which all of us are not adequately addressing." Quoted in The Globe and Mail, 16 May 1986.

'Ontario. Workers' Compensation Board, Annual Report (1986).

'T. Ison, The Dimensions of Industrial Disease (Kingston 1978) and R. Sass, "Workplace Health and Safety: Report From Canada," International Journal of Health Services, 16 (1986), 565 .
}

Eric Tucker, "Making The Workplace 'Safe' In Capitalism: The Enforcement of Factory Legislation in Nineteenth Century Ontario," LabourLeTravail, 21 (Spring 1988), 45-85. 
this paper to contribute to a discussion of these broad issues by examining the early development of occupational health and safety regulation in Ontario. Why was the state empowered to regulate occupational health and safety in the late nineteenth century, and why was this power exercised with such little effect?

This paper will focus on the later question. Aside from considerations of space, there are at least two reasons for concentrating on the implementation of Ontario's Factory Act rather than on its enactment. First, although no comprehensive study of the enactment of the Act has yet been published, a number of well-known works have touched on the subject.' No one, however, has yet examined the early implementation of that legislation. ${ }^{6}$ Second, the failure to study implementation reflects a tendency to conceptualize the state as a monolithic structure that can be analyzed primarily in terms of the activities of its more overt political institutions, processes, and figures. While these are obviously significant, both instrumentally and symbolically, a critical component of our understanding of the role and dynamics of the capitalist state will be lost unless adequate attention is focused on how state power is actually exercised by the officials on whom it is conferred.

The theoretical framework employed in this paper is premised on the view that there are structural imperatives in a capitalist social formation that weigh heavily on the choice and implementation of state policies. In particular, the state is constrained by the need to facilitate capitalist accumulation or to maintain "business confidence." The failure to do so is threatening to the state because it may lead to a decline in the level of private investment, which in turn may cause a drop in government revenue and an economic recession for which the state will be held responsible by the electorate. This pressure, however, does not invariably translate into state policies that facilitate capitalist accumulation. Dissatisfaction with the performance of the market also generates pressure on the state to protect subordinate classes. If the state fails to respond to this pressure it may suffer a loss of electoral support, or worse, face disruptions to the social and economic order. Thus, state policy is not determined by a logic of structural necessity. Rather, it is selected and

\footnotetext{
'The Ontario Factories' Act, 1884, S.O. 1884, c. 39.

'See Eugene Forsey, "A Note on the Dominion Factory Bills of the Eighteen-Eighties," Canadian Journal of Econumics and Political Science, 13 (1947), 580; Bernard Ostry, "Conservatives, Liberals, and Labour in the 1880's," Canadian Journal of Economics and Political Science, 27 (1961), 141; and Gregory S. Kealey, Toronto Workers Respond to Industrial Capitalism 1867-1892 (Toronto 1980). Also see, Linda Bohnen, "Women Workers in Ontario: A SocioLegal History," U.T. Fac. L. Rev., 31 (1973), 45.

"The only sustained study of the enforcement of factory legislation in Ontario is Michael Piva, The Condition of the Working Class in Toronto - 1900-1921 (Ottawa 1979) and, as the title indicates, it does not deal with the period from 1886-1900.
} 
implemented within a set of potentially contradictory constraints. Furthermore, these constraints do not exist independently of the actions taken by dominant and subordinant classes, even though these actions are themselves conditioned by a structural logic. Therefore, it is critical that we examine both the structural processes of capitalist development and the political organization and ideological orientation of different classes in order to understand state policy at a particular historical juncture.'

However, I also reject the view that the state's actions can be understood solely by reference to structural processes and class struggles taking place outside the state. Internal characteristics of the state including, its federal structure, the division of power between its legislative, executive and judicial branches, and its bureaucratic organization mediate social and political processes and affect state policy. As well, there are highly specific and, perhaps, contingent factors operating. Finally, no account of nineteenth century factory legislation can be complete if it focuses on class to the exclusion of gender. The development of industrial capitalism undermined familial patriarchy by removing the material basis of the father/husband's control over the family. State intervention needs to be analyzed from this perspective as well. ${ }^{8}$

By way of general background, then, the following points should be noted. Southern Ontario experienced a period of rapid industrial growth in the second half of the nineteenth century. Although this development was uneven, there can be no doubt that industrial capitalism emerged as a major force affecting the lives of Canadian workers. ${ }^{9}$ The introduction of steam powered machinery, new technologies, and large crowded workplaces combined with the intensification of the labour process through speed-ups, higher levels of supervision and discipline, piece work wages, and sweating produced serious occupational health and safety hazards for workers. As well, the introduction of wage labour drew women and children into the industrial labour force in increasing numbers. They were largely excluded from jobs traditionally performed by craftsmen, at least so long as craft control could be main-

\footnotetext{
'This framework reflects the views of neo-Marxist writers on the state including Claus Offe, Contradictions of the Welfare State (Cambridge 1984); Jurgen Habermas, Legitimation Crisis (Boston 1975); and Eric Olin Wright, Class, Crisis and the State (London 1978). For an excellent review of Marxist theories of the state see Martin Carnoy, The State and Political Theory (Princeton 1984). For a study of the development of state labour policy that applies this approach see Paul Craven, 'An Impartial Umpire': Industrial Relations and the Canadian State 1900-191/ (Toronto 1980), 157-67; 353-8.

${ }^{8} \mathrm{Jane}$ Ursel, "The State and the Maintenance of Patriarchy: A case study of Family, Labour and Welfare Legislation in Canada," in James Dickinson and Bob Russel, eds., Family, Economy and State (London 1986), 150.

${ }^{9}$ For an overview of this development see Kealey \& Palmer, Dreaming of What Might Be: The Knights of Labor in Ontario, 1880-1899 (Cambridge 1982), chap. 1.
} 
tained, and instead were ghettoized in positions that paid half the wages rates of men.

Initially, the state, through the courts, opted for a system of market regulation. That is, the courts refused to establish any obligation on employers to provide minimum levels of protection to employees. Rather, the matter was left to the labour market. In legal theory, workers and employers were juridical equals who met in the marketplace to bargain over the terms and conditions of employment. Other things being equal, workers would demand additional compensation to perform riskier jobs. Indeed, the courts constructed a legal presumption that workers had voluntarily assumed the risks that were present in their workplaces, including the risk of injury from the acts of fellow servants. Employers facing worker demands for risk premiums would decide whether it was cheaper to pay the premium or reduce the risk. The market would aggregate these individual decisions and economically efficient levels of health and safety would be produced. ${ }^{10}$

One way that workers responded to the selection of market regulation by the courts was to call on politicians to legislate minimum standards. Although this demand was initially made in the 1870 s, it was not until the 1880 s when labour was much better organized, that they were able to bring sustained pressure on the state to take action. Workers, however, were not the only group seeking state regulation of factories. Middle class reformers, imbued with Victorian notions of the family and femininity, saw the employment of women and children in factories as a dangerous practice, threatening to undermine the moral and physical foundations of the social order. Women were seen to be more physically vulnerable to the rigours of factory work, especially with regard to their reproductive capacity, and there was great concern that moral standards would decline if the sexes were not separated at work. Reformers also feared that children's physical development would be stunted, and that without proper education, they would develop into a class dangerous to the community. Thus, they too sought to have the state intervene to prevent these developments. Canadian manufacturers generally opposed factory legislation, but the Canadian Manufacturers' Association (CMA) was resigned to its inevitability. They recognized that factory legislation was a regular feature of industrialized economies and, as such, saw it as part of the price of the National Policy. They sought to delay its enactment and to insure that its impact would be moderate. In particular, they were concerned that power conferred on inspectors should be constrained, fearing that pro-labour inspectors would be appointed.

Although most political lobbying was directed at the Dominion government, factory legislation was first enacted provincially. For the Ontario Liber-

\footnotetext{
${ }^{10}$ Tucker, "The Law of Employers' Liability in Ontario 1861-1900: the Search for A Theory." Osgoode Hall Law Journal, 22(1984), 213.
} 
als under Mowat, the enactment of factory legislation provided an opportunity to simultaneously consolidate labour support and to assert a broad interpretation of the province's constitutional powers in circumstances in which it would be embarrassing for the Dominion government to challenge them. Although the Act was passed in 1884, it was not declared in force until 1886." This allowed the Liberals to claim credit with workers without needlessly antagonizing manufacturers. During this time the courts adopted a more de-centralized view of the British North America Act and the provincial Liberals sought to draw the Dominion government into litigation, but they declined. In 1886, the Liberals were able to claim credit with workers again by declaring the Act in force just on the eve of the appointment of the Royal Commission into Relations Between Labour and Capital by the Macdonald government.

The content of Ontario's factory act was shaped by these political forces. There were three kinds of provisions in the Act: those specifically regulating child and female labour; those regulating all factory work; and those dealing with administration and enforcement. It should be noted that the Act had limited application. As it name implies, it only applied to persons employed in factories. The Act did not define employee, but it did exclude persons engaged in repair work from its protection (s. 23). Section 2(1) defined factories broadly, but specifically exempted places employing less than twenty persons and, in some cases, private dwelling houses from its provisions. As well, section 21 exempted some private dwellings and factories not employing children and young girls from specific provisions relating to health conditions, posting and accident reporting requirements.

Children were defined as persons under the age of fourteen, and young girls were defined as girls between the ages of 14 and 18 (s. 2(5) and 2(6)). Section 5 imposed a general prohibition on the employment of children, young girls or women under conditions in which it would be likely that their health would be permanently injured. Violators were subject to imprisonment for six months or to a fine of up to $\$ 100$ plus costs. Section 6 of the Act specified a number of circumstances under which a violation of section 5 would be deemed to have occurred. First, it was unlawful to employ a boy under the age of 12 and a girl under the age of $14 .^{12}$ Boys between the ages of 12 to 14 could be employed provided the employer obtained a certificate attesting to the child's age from the parent or guardian (s. 6(2)). The parents of an under-age child found working in a factory were liable to be fined up to $\$ 50.00$ or imprisoned for up to 3 months (s. 17). To facilitate the enforcement of these age restrictions, the Act stipulated that persons found on fac-

\footnotetext{
"Public Archives of Ontario, RG3, O.C. 20/429, Order-in-Council, 5 Oct. 1886.

${ }^{12}$ Section $6(1)$. The original Bill made it illegal to employ children under twelve regardless of gender. It was amended at the urging of the TTLC to extend greater protection to young girls.
} 
tory premises were deemed to be employees and that if a child appeared to the court to be under-age, the burden lay on the defendant to prove the child was of legal age (s. 3). Second, a ten hour day and a sixty-hour week were established as the maximum hours of work for children, young girls and women, although the Act allowed some flexibility in order to permit a short day's work on Saturday (s. 6(3)). The Act also provided that the LieutenantGovernor could make regulations empowering the Inspector to issue overtime permits under certain circumstances, provided that work did not begin before 6 a.m. or end after 9 p.m., that hours did not exceed more than 12 $1 / 2$ in a day, or 72 in a week, and that overtime was not worked more than six weeks a year." As well, section 9 required employers to maintain a register of overtime worked pursuant to the inspector's permit. Notice of the hours of work was required to be posted on prescribed forms. Third, women and children were entitled to a one hour lunch break and the inspector was given the authority to order that lunch not be taken in a work room, but rather in a suitable dining room provided by the employer at his own expense. Finally, the Act prohibited women and children from performing certain duties that could be performed legally by adult males. Section 7 made it unlawful to allow women and children to clean machinery while it was in motion and children and young girls were prohibited from working in certain positions around powered machinery in motion.

The second set of provisions provided protection for all workers in factories. Section 14 imposed a general duty on employers not to "keep a factory so that the safety of any person employed therein is endangered, or so that the health of any person employed therein is likely to be permanently injured." Violators were subject to a fine of up to $\$ 500.00$ or imprisonment for up to one year. The Act deemed a number of conditions to be violations of section 14. For example, section 11 created minimum standards regarding cleanliness, overcrowding, ventilation and closet accommodation, including a requirement for separate closet facilities for men and women. Section 12 required employers to comply with orders made by the inspectorate in relation to the above matters within a reasonable time. As well, the section specifically gave the inspector the authority to order that mechanical means, approved by regulation, be installed in order to eliminate injurious levels of dust. Section 15 required fencing of machinery "as far as practicable;" guarding openings of hoistways etc.; and safety devices for elevators. Section 16 created standards with respect to fire safety including: the provision of fire extinguishers "as the Inspector, acting under the regulations made in that behalf, directs in writing;" outwardly opening exit doors;

\footnotetext{
${ }^{13}$ Section 8. The circumstances in which overtime was permitted included machinery breakdown and "the customs and exigencies of certain trades."

${ }^{14}$ The original Bill did not include a general duty to protect the health of the worker.
} 
and fire escapes of certain specifications, "Provided, always, that any of the requirements of this sub-section may be dispensed with in any factory if the inspector so directs."

The last set of provisions related to administration and enforcement. The Act provided for the appointment of one inspector by the LieutenantGovernor in Council (s. 2(2)). The inspector was empowered to enter and inspect factories at all reasonable times without a warrant, unless the premises were also used as a dwelling (s. 25(1), 26). For the purposes of ascertaining whether factories complied with health requirements of section 12, the inspector was authorized to call upon the assistance of a physician or local health officer (s. 13). In any case where there was fear of obstruction, the inspector could call upon a constable for assistance (s. 25(3)). As well, the inspector was empowered to require the production of registers or other documents required to be kept by the Act, and to examine any person found in a factory with respect to the requirements of the Act (s. 25(2), 25(4)-(6)). Finally, the inspector was given general authority to "exercise such other powers as may be necessary for carrying this Act into effect" (s. 25(7)). Any person who obstructed an inspector in the execution of his or her duty was liable to a fine (s.25).

In order to assist the inspector, employers were required, in some circumstances, to notify the inspector in writing within six days of deaths or serious injuries requiring employees to be off work for more than six days $(s .18,19),{ }^{16}$ and to notify the inspector within one month after they began to occupy a factory (s.28(1)). The Act also required that certain notices be given to employees, including, notice of the provisions of the Act ("as the Inspector deems necessary"), and notice of the name and address of the inspector (s. 29).

Prosecutions under the Act were to be brought before two justices of the peace in the county in which the offence was alleged to have been committed (s. 39). Informations had to be laid within two or three months after the commission of the offence (s. 38(1)), depending on the offence. Convictions were not to be quashed for defects in form, and there was a preclusion of certiorari except for the purposes of hearing a special case (s. 38(6)). In addition to the power to fine or imprison, the court was given the authority to order that certain means be adopted in order to bring the factory into conformity with the Act (s. 32).

\footnotetext{
${ }^{15}$ The discretion to dispense with the fire safety requirements was not in the original Bill.

${ }^{10}$ The original Bill required that notice be given whenever the injury required the worker to be off work for forty-eight hours.
} 
The Implementation of the Act, 1886-1900

Although THE ACt CAME INTO FORCE on 1 December 1886, no arrangements for its enforcement were made until the spring of 1887 . Clearly, these arrangements were critically important if the Act was to protect workers. The Act vested inspectors with broad discretionary powers to determine its operative meaning, and the government determined the resources committed to factory act enforcement. The most important question was not whether the state and its agents had then sufficiently empowered, but rather whether, and to what extent those powers would be exercised for the benefit of workers.

\section{A. Setting Up the Administration of Enforcement}

Manufacturers and workers realized this and actively lobbied the government to insure that arrangements satisfactory to their interests were made. In response to earlier Dominion bills, manufacturers had expressed their concerns regarding implementation, and in particular, the powers given to the inspectorate." Thus, it was not surprising that when a special meeting of the CMA was held on 30 November 1886 to discuss the Ontario Act, most of its provisions were found to be unobjectionable, "if properly applied, but there was also considerable anxiety displayed at the unlimited powers vested in the factory inspectors." "A committee of leading industrialists, including H. A. Massey, J. Inglis, and Frederic Nicholls, was appointed to meet with Mowat to discuss the appointment of inspectors. At that meeting, the committee expressed its concern over the inspector's powers and its fear that a pro-labour inspector, whose decisions would be virtually unappealable, could put manufacturers to immeasurable expense. The delegation proposed that the government should appoint competent and impartial men drawn from the ranks of labour and capital so that, in the event of a dispute, consultation would be facilitated.'

The Toronto Trades and Labor Council (TTLC) was equally active in lobbying the government. Even before the Act was declared in force, efforts were made to have local inspectors appointed. ${ }^{2 n}$ Subsequent to its proclama-

\footnotetext{
'For example, at a meeting of the Ontario Manufacturers' Association called to discuss the Dominion Bill of 1883, it was agreed that too much power was given to the inspectors and that there were insufficient safeguards for manufacturers "who might become their victims." The Globe, 28 April, 1883.

${ }^{18}$ Public Archives of Canada, Canadian Manufacturers Association Papers, MG 28, 1230, Minutes, Special Meeting, 30 Nov. 1886; Globe, 1 Dec. 1886.

${ }^{19}$ Canadian Manufacturer, 6 May 1887. (hereinafter $C M$ )

${ }^{20}$ See The Globe, 3 Sept. 1884 for an account of a discussion in the Fire and Cias Committce of Toronto City Council about appointing a local factory inspector or petitioning the provincial government to do so.
} 
tion, meetings were held in November 1886 at which resolutions were passed calling on the government to appoint inspectors who possessed the confidence of wage earners at large, and who were either nominated, or at least approved by labour organizations. Potential nominees were discussed, but it was not deemed expedient to forward specific candidates for consideration by the government. ${ }^{21}$ The Toronto Evening News published an editorial supporting labour's concerns over the appointment process.

A good deal of wire pulling is going on with regard to the appointment of Inspectors of factories.... Some persons are mentioned who have no qualifications whatever ... other than that always essential one in the eyes of a party government, activity as political heelers. We do not, of course, expect anything so utopian as the appointment of any official on the sole ground of fitness.... But the labour organizations do expect that the inspectors ... shall, in addition, be competent men, and in synpathy with the cause of Labour Reform. If mere timeservers and political heelers are chosen, the Act will be a failure. ${ }^{22}$

As a result of these lobbying efforts, and others, two amendments to the Act were introduced into the Legislative Assembly on 7 April 1887 by the government. The first created a special exemption from the prohibition on child labour, while the second provided for the appointment of regional inspectors instead of the single inspector that was provided for in the original Act. Although both labour and capital supported the appointment of more than a single inspector, their reasons for doing so were quite different. The CMA feared that if only one was appointed, he would likely be a labour supporter. Therefore, they favoured the appointment of at least two inspectors, but probably not many more, in the hope that the second would have the confidence of the manufacturers. Labour, on the other hand, wanted local inspectors to be appointed in order to ensure that sufficient resources would be devoted to enforcement. William Meredith, leader of the Tory opposition, sought to enhance his party's standing amongst workers by proposing that there should be an inspector for each county appointed by the country council. C. F. Fraser, Commissioner of the Department of Public Works, replied that this would be impossible and that the government did not intend to appoint more than two inspectors." This position was in line with the views of the CMA. ${ }^{.4}$ The amendments were passed and received Royal Assent on 23 April 1887."

This cleared the way for the appointment of inspectors, but still did not resolve the question of how many would be appointed, from what backgrounds they would come and how the province would be divided between them. The government ultimately decided to appoint three inspectors instead

\footnotetext{
"Toronto Trades and Labour Council, Minutes, 5, 19 Nov. 1886.

"Toronto Evening New's, 22 April 1887.

"Ontario. I.egislative Debates, Globe, 20 April 1887.

${ }^{-4} \mathrm{CM}, 6$ May 1887.

"s.o. 1887 c.35 (Ont.).
} 
of two as Fraser had earlier declared. Although the reasons for this are unclear, if may have been done to counter Meredith's attempt to outflank the government by supporting labour's preference for the appointment of numerous local inspectors. ${ }^{26}$

Whether the CMA or labour organizations were consulted with respect to particular individuals is unknown, ${ }^{27}$ but the strategy followed by the government seems fairly apparent upon examination of the appointments made by Order in Council on 25 June 1887, effective $1 \mathrm{July} .{ }^{28}$ The province was divided into three districts with an inspector for each one. Robert Barber, a manufacturer from Toronto was appointed inspector of the western district, including Toronto west of Yonge Street. James R. Brown, a mechanic from Oshawa was appointed inspector of the central district, including the eastern half of Toronto, and O. A. Rocque, an ex-alderman from Ottawa, was appointed inspector for the eastern district. Thus, we can see that the politically sensitive, and heavily industrialized south central area was divided between two inspectors, one drawn from the ranks of labour, and the other from the ranks of the manufacturers. Meanwhile, the less industrialized eastern and northern areas of the province were assigned to Rocque, who, as far as can be determined, was a patronage appointment, pure and simple. Further, as between Barber and Brown, Barber was given the more heavily industrialized western sector. ${ }^{29}$ The pro-government Globe greeted the announcement of the appointments predictably. They congratulated the government "on having secured the services of men so competent and at the same time so acceptable to all whose interests are concerned in the just and fair administration of the factory laws." 30

\footnotetext{
${ }^{\text {2h }}$ See Public Archives of Ontario, R.G.15, Series S-2, No. 1014, Letter from Edwards, Secretary, Public Works Department, Ontario, to William Mack, MPP. Cornwall in response to a petition he presented signed by citizens of Cornwall in May-June, 1888, calling for the appointment of a local inspector. The pattern of party competition for labour support during this period has been noted by numerous commentators including Kealey, Toronto Workers. "In a debate over factory inspection that took place at the Seventh Annual Conference of the Trades and Labour Congress of Canada (TLCC) held in 1891, A. W. Wright, a labour "leader" with a rather checkered career (see, Kealey and Palmer, Dreaming, 177-87) asserted that labour organizations were not consulted in the appointment of inspectors. See, The Labour Advocate, 11 Sept. 1891. With regard to the CMA, a circular letter dated 29 April, 1887 called for a general meeting to discuss, amongst other issues, recommendations for the appointment of a factory inspector. However, the Minutes of the meeting that took place on 4 May do not indicate whether the question was discussed.

:Public Archives of Ontario, R.G.3, O.C. 21/288.

i" See Ontario, Department of Public Works, Report of the Inspectors of Factories, 1888 (Toronto 1889). (Note: The Report was published annually in the Sessional Papers of the Province. After 1888, the Inspectors reported to the Department of Agriculture. These reports are hereinafter cited Inspectors of Factories, Year.)
}

"Globe, 23 June 1887. 
Little is known about the backgrounds of Barber and Rocque beyond the brief descriptions given above. ${ }^{31}$ James Brown's career prior to his appointment is better documented. His roots as a labour activist reach back to the nine hour movement of $\mathbf{1 8 7 2}$ during which he emerged as a labour spokesman in Oshawa. He helped establish a branch of the Knights of Labour in Oshawa in 1882 and served as secretary of the Oshawa Trades and Labour Council, as well as chairman of its Legislative Committee. ${ }^{32}$ However, he also had a connection with the Liberal Party through D.J. O'Donoghue, and acted as the Oshawa correspondent for the Ontario Bureau of Industries after it began collecting labour statistics. ${ }^{33}$

Neither the CMA nor the TTLC commented on the appointments. However, it is quite likely that Brown's appointment disturbed the CMA. Not only was he an active and militant trade unionist, he had seriously antagonized employers in Oshawa earlier in the 1880s by arguing that labour should be made the measure of all value in order to prepare the way "for industrial co-operation on an equitable basis." Such a step would, in Brown's view, "revolutionize the world." $34 \mathrm{He}$, along with numerous other labour activists of the time, was influenced by the ideas of Henry George, and had urged the delegates to the Labour Congress convention of 1883 to study Poverty and Progress. "Shortly before his appointment was announced, he became embroiled in a nasty exchange with the CMA over resolutions he had introduced as a delegate to the TLCC convention in September 1886. Petitions to the government based on these resolutions were attacked by the CMA, and Brown defended them vigorously in a letter to the CMA dated 16 May 1887.

It is a sad commentary on the boasted civilization and Christianity of the age that the selfishness and greed of one class of the community has enabled that class to successfully manipulate the representatives of the people, and to obtain the power which enables that class to set at defiance the petitions of labour for justice.

The over-bearing arrogance of employers towards employees is too often the cause of strikes, and the indifference of employers to the welfare of workers has been the cause of untold suffering.

The CMA was alarmed by Brown's letter and on 23 May, they reproduced it in a circular calling for an emergency meeting to discuss it. ${ }^{36}$ The outcome

\footnotetext{
"In R. L. Polk and Co. 's Toronto City Directory (1884-5), a firm by the name of Robert Barber Jr. \& Co. is listed as a manufacturer of woollen goods. O. A. Rocque served as an alderman in Ottawa from 1872-76. See, Historical Sketch of the County of Carlton (Toronto 1879) 176-7. ${ }^{32}$ Kealey and Palmer, Dreaming, 342-3.

${ }^{13}$ The Bureau began collecting labour statistics in 1883 at the request of the Labour Congress which met in Toronto in December, 1883. For Brown's report on Oshawa see Ontario, Bureau of Industries, Annual Report, 1884 (Toronto 1885), Ixxii.

${ }^{14}$ Quoted in Kealey and Palmer, Dreaming, 343.

"Cited in Ramsay Cook, The Regenerators: Social Criticism in Late Victorian English Canada (Toronto 1985), 114.
}

${ }^{16}$ See CMA, Circular Letters, 23 May 1887. 
of the meeting is unknown, but the antagonism between Brown and the CMA intensified when Brown spoke out against legislation introduced into the Dominion Parliament on 10 June 1886 designed to break the control of Quebec dock workers who were able to make membership in their association a condition of employment. ${ }^{37}$ On 1 July, the day Brown's appointment became effective, $C M$ ran an editorial rebuking him for supporting trade union interference with individual rights of contract. In the same issue of $C M$, the appointment of the factory inspectors was noted without comment. ${ }^{38}$

The inspectors were initially placed under the supervision of the Commissioner of Public Works, C. F. Fraser. They received an annual salary of $\$ 1,000$ dollars and ample provision was made for their expenses. ${ }^{39}$ Upon assuming their duties on 1 July 1887, the inspectors were instructed to use the remainder of the year to make informal visits to the larger factories under their jurisdictions for the purpose of introducing themselves, distributing copies of the Act and ascertaining the degree of compliance with the Act." These instructions were reflected in the descriptions of the inspectors' visits provided by witnesses appearing before the Royal Commission on Relations of Labour and Capital in the fall of 1887." Thus, it is not surprising that the Second Report of the Royal Commission found that existing factory legislation was largely inoperative. ${ }^{42}$

While the inspectors were out in the field introducing themselves, the government made additional arrangements for the enforcement of the Act. A regulation was prepared which prescribed various forms to be used for

\footnotetext{
"For an explanation of the bill see Canada, House of Commons, Debates (1887), 862.

${ }^{\text {ix }} C M, 1$ July 1887. Subsequent to his appointment, $C M$ criticized Brown for some comments he made on the dock workers' legislation and for advocating the nationalization of the railways. $C M$ never criticized the government for appointing Brown, and they never criticized him for his activities as a factory inspector.

${ }^{14}$ Public Archives of Ontario, R.G. 3, O.C. 21/288, Order-in-Council, 25 June 1887 contains the terms of their appointment. The annual travel expenses incurred by inspectors Brown and Barber averaged between $\$ 500.00-600.00$ each. Inspector Rocque's were considerably less. The expenses incurred in enforcing the Act were reported annually in Public Accounts, published in the province's Sessional Papers.

"Sce, Inspectors of Factories, 1888, 5 (per Barber); and Brown's testimony before the Royal Commission on Relations Between Labour and Capital (RCRLC) given in fall 1887. See RCRLC, Evidence-Oniario (Ottawa 1889), 315-20.

"For example, Thewilis Day, superintendent of the Cornwall Manufacturing Co., Cornwall, described how Inspector Rocque went through the factory's twelve rooms in 25-30 minutes, without consulting any of the operatives, and declared himself satisfied. RCRLC, Evidence. 1071-2. Also see the restimony of Samuel Peddle, cabinetmaker, London, 633. The only manufaclurer who reported receiving directions from an inspector was Joseph Firstbrooke, a Toronto box manufacturer, who was instructed by Inspector Brown to place a trap door over a hatch. uay, 312

"RCRLC, Second Repert. 79. The first report did not comment on the implementation of the Act. but did make recommendations for its enforcement. RCRI.C. First Report, 11.
} 
giving notices and for keeping registries required by the Act. It gave the inspectors authority to grant overtime permits pursuant to section 8 , subject to prior approval by the Commissioner of Public Works. Finally, section 7 of the regulations instructed the inspectors to take into account "any special circumstances" which in their opinion "should be considered on behalf of the employers" when issuing remedial orders for violations of the health requirements of section $11 . .^{4}$ Arrangements were also made with labour unions to have their members' complaints funnelled through the union to the inspectors and the inspectors were instructed to receive complaints in this manner. ${ }^{44}$ There is no record of other instructions from the government to the inspectors. ${ }^{45}$

\section{B. The Inspectors Take to the Field}

In evaluating the implementation of factory legislation, it is necessary to face the challenge posed by some recent writers who dispute the 'standard' account of the ineffectiveness of factory regulation. The 'standard' account notes the inspectors' failure to vigorously exercise their prosecutorial powers and concludes that the Act was largely unenforced. The failure to prosecute employers is linked to a broader analysis of the limited ability of the state to regulate against the interests of capital because of the significance of class power. The 'conventionalization' of factory crime was a means of blunting the impetus towards regulation in order to avoid the untenable spectacle of the state criminalizing the behaviour of the most powerful social class. ${ }^{*}$

The essence of the revisionist critique is that the standard account incorrectly assumes that compliance could only be achieved by means of prosecution. It is their thesis that the inspectors chose persuasion and bargaining as an alternative enforcement strategy, and that this choice was justified because it made more efficient use of the limited enforcement resources avail-

\footnotetext{
${ }^{43}$ Public Archives of Ontario, R.G. 3, O.C. 21/530 The Ontario Factories' Regulations (first series), 1887, issued 29 November 1887.

${ }^{44}$ See, Report upon the Sweating System in Canada, Supplementary Report (House of Commons, Session Paper 61a, 1896), 32, where Inspector Brown reported that, at the time of his appointment, he was informed by $\mathrm{C}$. F. Fraser, then Commissioner of Public Works, that a reporting arrangement had been worked out with the unions. Brown also referred to Fraser's original directive in his last report as an inspector. See Inspectors of Factories, 1902, 18.

4 "Inspector Brown was asked in his appearance before the RCRL.C. "Have you been instructed to use persuasion rather than to prosecute?" Before Brown answered the Chairman interrupted to suggest that the question was improper, and no answer was given. See RCRLC, Evidence, 320.

the most sophisticated presentation of this thesis is that of W. G. Carson, "The Conventionalization of Early Factory Crime." International Journal of the Sociology of Law, 7 (1979), 175 .
} 
able. Not only does this analysis serve to vindicate the inspectors by depicting them as ingenious and spirited individuals, battling against stiff odds in an attempt to implement the legislation. It also serves to vindicate a positive perception of the liberal, pluralist democratic state by denying the significance of class power in determining the behaviour of the state and its agents. Instead, it portrays the state as an effective instrument for articulating and achieving outcomes that reflect community consensus."

This critique forces us to confront the fact that there are a range of enforcement strategies, and that the mere fact that a prosecutorial strategy was not chosen is not, in itself, sufficient evidence to justify the conclusion that legislation was not enforced. In examining the enforcement process in Ontario we will first identify the strategy selected by the inspectors, and then assess the reasons for its selection and its impact on the way compliance came to be defined by the inspectors.

\section{Enforcement Strategy: Prosecution or Persuasion}

In a prosecution model of enforcement, heavy reliance is placed on the detection, prosecution and punishment of violators. In a persuasion model, the emphasis is on bargaining in order to secure "voluntary" compliance. These models can be seen to mark the end points of a continuum. In practice, most enforcement agencies use some mixture of prosecutorial and persuasion strategies. Our first task is to identify and locate the strategy adopted by the Ontario's factory inspectors on this punishment-persuasion continuum.

The model of enforcement that was adopted form the time formal enforcement of the Act commenced on 1 January 1888 to the end of the century was that of persuasion, practically to the exclusion of any coercive element whatsoever. This is clearly indicated by Table 1 below.

The table shows that in the first 12 years of the Act's operation a total of 35 charges were prosecuted. Four charges were laid against parents for allowing their under-age children to work. In a number of instances, several charges were laid against a single employer, and so the total number of em-

\footnotetext{
${ }^{47}$ See, Bartrip \& Fenn, "The Conventionalization of Factory Crime - A Re-assessment, International Journal of the Sociology of Law, 8 (1980), 175 and "The Evolution of Regulatory Style in the Nineteenth Century British Factory Inspectorate," Journal of Law \& Society, 10 (1983), 201. Also see Harry Arthurs, 'Without the Law': Administrative Justice and Legal Pluralism in Nineteenth-Century England (Toronto 1985), 103-115 who is more sensitive to class factors, but who, nevertheless, sees factory inspectors as a proto-type of the model professional administrator who vindicates his faith in public administration and legal pluralism.

There is a burgeoning literature that explains current enforcement practices on a similar basis. For example, see Hawkins, "Bargain and Bluff: Compliance Strategy and Deterrence in the Enforcement of Regulation, Law \& Politics Quarterly, 5 (1983), 35 and Veljanovski, "Regulatory Enforcement: An Economic Study of the British Factory Inspectorate," Law \& Politics Quarterly, 5 (1983), 75.
} 


\begin{tabular}{|c|c|c|c|c|}
\hline \multirow[b]{2}{*}{ Year } & \multicolumn{3}{|c|}{$\begin{array}{c}\text { TABLE 1 } \\
\text { Prosecutions 1888-1900 } \\
\text { No. of Charges Prosecuted }\end{array}$} & \multirow[b]{2}{*}{ Tota } \\
\hline & Barber & Brown & Rocque & \\
\hline 1888 & 1 & & & 1 \\
\hline 1889 & & 10 & & 10 \\
\hline 1890 & & 5 & & 5 \\
\hline 1891 & & 5 & & 5 \\
\hline 1892 & & & & 0 \\
\hline 1893 & & & 1 & 1 \\
\hline 1894 & & & & 0 \\
\hline 1895 & & & & 0 \\
\hline 1896 & 1 & 1 & & 2 \\
\hline 1897 & & & & 0 \\
\hline 1898 & & 5 & & 5 \\
\hline 1899 & $1 *$ & & & 1 \\
\hline 1900 & & 5 & & 5 \\
\hline Totals & 3 & 31 & 1 & 35 \\
\hline
\end{tabular}

*Not mentioned in inspector's reports, but reported in R.V. Weir (1899) 20 C.L.T. 232. Source: Report of the Inspectors of Factories, 1888-1900.

ployers prosecuted is less than 31 . On average, less than three charges were prosecuted per year. Of these, all but two were for violations of the provisions regarding the employment of women and children and hours of work in bake shops. In the two cases involving violations of health and safety provisions of general application, one related to ventilation, ${ }^{48}$ while the other involved a breach of the general duties clause. ${ }^{49}$ During this same period, there were 207 reported fatal accidents and 2,632 reported accidents causing serious injury. In none of these cases was the employer prosecuted for violating the Act. ${ }^{\text {so }}$

One further point must be noted. Thirty-one out of the 35 charges

\footnotetext{
${ }^{48}$ In 1898 Thomas Carroll was fined $\$ 2.00$ for failing to provide adequate ventilation of dust for emery wheels. Inspectors of Factories, 1898, 19.

${ }^{49} R$. v. Weir (1899), 20 C.L.T. 232. The defendant was convicted at first instance, but the conviction was quashed on the ground that three out of the seven persons present in the factory were employers. This reduced the number of employees to four, below the treshold for the application of the Act.

${ }^{\text {ST }}$ The inspectors annually reported on the accidents in their districts, In two cases in which boys between 12 and 14 were seriously injured or killed, the employer was prosecuted for failing to obtain a certificate of age. Inspectors of Factories, 1891, 14.
} 
prosecuted were initiated by Inspector Brown. This suggests that he was far more willing than his colleagues to resort to prosecution as an element of the enforcement process. The reasons for this difference, and its significance for our understanding the choice of enforcement strategy generally, will be explored in the following sections of the paper.

Did the inspectors choose persuasion because it was more efficient as the revisionists suggest, or did they do so because of the pervasive influence of class power? It will be argued here that the efficiency explanation does not escape the reality of class power, but merely masks it. This occurs because that approach treats the material and ideological constraints under which the inspectors operated as natural facts, unrelated to class and politics. This will be shown to be an untenable assumption.

The resources devoted to enforcement of the Act were inadequate from the outset, and the situation deteriorated during the 1890's. In 1888, Barber found 375 factories in his district which spread out over 18 counties and the western half of the City of Toronto. Brown found 224 factories spread out over 16 countries and the eastern half of the City of Toronto. Rocque did not report the number of factories in his jurisdiction but, we can safely assume that there were fewer than in Brown's, and that they were even more widely dispersed over nine counties and six districts. Barber reported that on his first formal inspection tour he was able to visit all the factories in his district by October, and then was able to conduct repeat visits of factories employing women and children. One can imagine the cursory nature of the inspections that were conducted in order to cover so much ground so quickly. As well, the inspectors claimed that they managed to visit factories within their districts that were not covered by the Act."

The workload of the inspectors increased substantially in 1889 as a result of an amendment to the Act which made factories employing more than five persons subject to its provisions. ${ }^{2}$ Inspector Barber reported that the alteration in the definition of a factory more than trebled the number of establishments requiring inspection." Despite this enormous increase in workload, there was no increase in the complement of inspectors until 1895 when Margaret Carlyle was appointed as female inspector of factories with a jurisdiction limited to issues affecting child and female labour. ${ }^{54}$ By 1901 there were 6,543 manufacturing establishments in Ontario employing more

\footnotetext{
"Inspectors of Factories, 1888.

${ }^{52}$ The Ontario Factories' Amendment Act, 1889, S.O. 1889 c.43, s. 3(2).

"Inspectors of Factories 1889, 6.

${ }^{54}$ In her first years on the job she claimed to cover so much ground that, by comparison, her male colleagues' looked like slackers. In her first half year she made 611 inspections in 43 cities and in her first full year, she inspected 986 establishments, many of them several times. Inspectors of Factories, 1895, 23 and Inspectors of Factories, 1896, 20.
} 
than five persons, and still only four inspectors. ${ }^{\text {s }}$ As well, the factory inspectors were given responsibilities under legislation regulating bake shops in 1896 and commercial shops in $1897 .^{\text {s6 }}$

Although the resources of the inspectors were not as thinly spread in 1888 as they were in 1901, the problem of limited resources always constrained their selection of enforcement strategies. A strategy that heavily depended on frequent and thorough inspections to detect and remedy violations of the Act was simply not feasible under the circumstances. A negotiation strategy may have been more efficient. But, even if it was, it is important to remember that negotiating compliance is not a costless strategy. The ability of inspectors to effectively pursue this strategy would also be constrained by resource scarcity. Indeed, it is likely that inadequate enforcement resources were a more direct and significant determinant of the limited impact of factory legislation than was the choice of enforcement strategy.

Moreover, the scarcity of resources was not a natural condition, but a politically created fact. While it is clear that the state would not, indeed, could not, provide unlimited resources for the enforcement of the Act, and in that sense scarcity was inevitable, the important issue was the degree of scarcity. The question of the initial commitment of resources to enforcement was, as noted, the subject of dispute between labour, which sought the appointment of numerous local inspectors, and the government, which thought the proposal "impossible." "s' The decision to appoint three inspectors did not end the matter. Labour continually complained about inadequate enforcement and lobbied the government to appoint additional inspectors and to provide permanent ones for manufacturing centres. ${ }^{88}$ The decision to limit the resources available for enforcement was clearly a political one, taken in the context of the class politics of the period, and not simply an expres-

\footnotetext{
${ }^{3}$ Census of Canada, 1901. Prior to 1901, census data was collected with respect to all manufacturers regardless of their size. It is therefore impossible to use that data as a basis for calculating the inspectors' workload. From 1901 onwards, data was only collected for manufacturers employing five or more persons.

"The Bake Shops' Act, 1896, S.O. 1896, c. 64, s. 9; An Act respecting Shops and Places other than Factories, S.O. 1897, c. 51, ss. 2(b), 18(2). The later Act gave the Lieutenant Governor in Council power to appoint inspectors, but did not stipulate that they were to be the factory inspectors. Nevertheless, the factory inspectors were made inspectors under this Act. See Public Archives of Ontario, R.G. 3. O.C. 34/426, Order-in-Council dated 8 May 1897.

"See above.

¿\$ For example, in the spring of 1888 the government received a petition signed by 470 citizens of Cornwall requesting the appointment of a local inspector. Public Archives of Ontario, R.G. 15, Series S-2, No. 1014. Later that year the TLCC passed a resolution calling on the government to appoint local inspectors. Resolutions to the same effect were also passed in 1891 and 1897. See TLCC, Proceedings for the above years and The Labour Advocate, 11 Sept. 1891.
} 
sion of some undifferentiated community consensus. 99

The lack of resources was not the only constraint on the inspectors when selecting an enforcement strategy. The inspectors also had to consider political controls on their behaviour and to cope with the administrative arrangements made for the prosecution of cases. In Ontario neither the decision to prosecute, nor the conduct of the prosecution were entirely in the hands of the inspector. Although practices may have varied, there is evidence to suggest that the inspectors were required to consult with the Deputy AttorneyGeneral before laying charges and that the actual prosecution was left to the local Crown Attorney. ${ }^{60}$ However, it is not clear whether this aspect of the arrangements constrained the inspectors' freedom to prosecute. There is at least one case in which an inspector was advised not to prosecute ${ }^{61}$ but, in another, Inspector Brown was criticized by the Attorney-General's department for only prosecuting three out of a possible eighteen charges against an employer who had worked female employees in excess of the hours permitted under the Act. ${ }^{2}$ Indeed, in that same report Inspector Brown indicated that the Deputy Attorney-General had expressed the view that sufficient time had elapsed for employers to become acquainted with the provisions of the Act and that ignorance was no longer an excuse for its contravention. ${ }^{63}$ This suggests that it was not resistance from the Attorney-General's of fice that was constraining the inspectorate. Rather, the evidence suggests that permission to prosecute was rarely sought by the inspectors in the first place. ${ }^{\text {ts }}$

This may have been due to the government's reputed attitude toward prosecution rather than to any direct interference by the Attorney-General's office. There is some evidence suggesting that the inspectors were given general instructions to be "reasonable" and to avoid confrontations with employers. For example, in 1895 Inspector Barber noted that the inspectors "understand it to be the wish of the Government that the Factories' Act shall be enforced in an efficient manner, with as little friction and annoyance as possible." A further indication of the government's negative attitude

\footnotetext{
${ }^{59}$ See Bartrip \& Fenn, "A Re-assessment," 182 for the assertion that the level of resources devoted to enforcement was a decision of an undifferentiated community. See Carson, "Early Factory Inspectors and the Viable Class Society - A Rejoinder," International Journal for the Sociology of Law, 8 (1980) 187, 190 for a critique of Bartrip \& Fenn's usage of the notion of community in the context of nineteenth century Great Britain.

${ }^{6}$ Inspectors of Factories, 1890, 21 and 1896, 15.

${ }^{61}$ Inspectors of Factories, 1898, 9.

${ }^{62}$ Inspectors of Factories, 1890, 21. Inspector Brown acknowledged his error and promised to prosecute every case in the future.

${ }^{63} \mathrm{Ibid}$.

${ }^{64}$ In the inspectors' correspondence from 1898-1900, I found only one letter in which permission to proscecute was sought. James R. Brown to John Dryden, Minister of Agriculture, 27 Sept. 1898.

${ }^{65}$ Inspectors of Factories, $1895,7$.
} 
toward prosecuting employers arose from a meeting in 1897 between the Executive Committee for Ontario of the TLCC and the Minister of Agriculture to discuss the enforcement of the Factory laws. ${ }^{\text {to }}$ The Committee brought to the Minister's attention complaints being made by the Hamilton TLC, amongst others, that "the Government will not allow the inspectors to enforce the Act" and urged him to be more energetic. The Minister is reported to have replied that "he was heartily in sympathy with the cause of labour, and that it was not the Government's object to secure convictions and fines as it was to cause a due observance of the laws by quiet means." ${ }^{\prime 6}$

In sum, it is difficult to state conclusively the extent of direct Government control over the decision-making of the inspectorate. To the extent that the inspectors faced political or administrative obstacles to prosecution, it was rational for them to resort to an alternate strategy. However, to simply explain the choice of enforcement strategy on the grounds of efficiency or rationality obscures the central importance of class politics in shaping the formation of implementation policy.

Another reason given for the decision not to pursue a more prosecutorial strategy was that the inspectors met with judicial hostility when they attempted to do so. Although frequent complaints of this nature were made by inspectors in other jurisdictions, no such allegations were made by the Ontario inspectors during this period. As well, although the labour movement consistently complained about many aspects of the implementation of the Act, I have only discovered a single instance in which the judiciary was criticised for being "exacting" and "almost always against the interests of the working people immediately concerned" in their application of both the Factories Act and the Workmen's Compensation For Injuries Act. ${ }^{88}$ The lack of judicial hostility to the inspectors can also be inferred from the results of the cases they brought. Convictions were obtained in 20 out of the 35 charges laid. In nine cases the court gave the defendants time to comply with the inspectors orders, and in one of those, a conviction was later obtained when the defendant failed to do so. There were only three outright acquittals. Although the fines were generally quite low, they were usually in line

\footnotetext{
"The factory inspectors were placed under the authority of the Minister of Agriculture in 1889.

${ }^{67}$ TLCC, Proceedings (1897), 11.

${ }^{\text {sN }}$ This was contained in a report of the Legislative Committee of the TTLC. See Labour Advocate, 10 July 1891.
} 
with the amounts suggested by the inspectors, and certainly did not arouse their ire. ${ }^{\text {. }}$

Another external factor offered as an explanation of why it was rational for inspectors not to prosecute is that the legislation itself created procedural or substantive hurdles which made prosecutions difficult to conduct successfully. One such difficulty was the requirement in section 38 of the Act that an information had to be laid within two or three months of the occurrence of the violation, depending on the penalty. The non-reporting of serious accidents frequently resulted in the inspectors discovering the accident only after the period had elapsed, and was offered as a reason for not prosecuting. ${ }^{70}$ This explanation is not convincing because, even after section 38 was amended in 1895 to eliminate the possibility that immunity could be acquired by nonreporting," there was no increase in prosecutions.

A second possible difficulty with the Act was that the standards that employers had to satisfy were prescribed in open-ended language. For example, there was no definition of overcrowding (s. 11(2)). Factories had to be ventilated "so far as is reasonably practicable" (s. 11(3)), and moving parts of machinery had to be "as far as practicable, securely guarded" (s. 15(1)). Initially it was contemplated that regulations defining these requirements would be promulgated, but by 1889 it was recognized that enforcement would have to proceed in their absence, and the Act was amended accordingly." The absence of objective standards could have made it more difficult to establish that the Act had been breached. It is by no means clear, however, that this proved to be a problem in the few charges laid pursuant to sections worded in these ways that were brought under section 14. For example, in the one case brought under the general duty requirement, a conviction was obtained at first instance, although it was subsequently quashed on unrelated grounds. ${ }^{3}$ As well, in another case, a conviction was obtained for inade-

\footnotetext{
${ }^{69}$ For discussions of difficulties inspectors experienced with the courts in other jurisdictions see, C. Walker, A History of Factory Legislation and Inspector in New York State, 1886-1911 (Ph.D. thesis, Columbia University, 1969), 221-8; Bartrip and Fenn, "The Administration of Safety: The Enforcement Policy of the Early Inspectorate, 1844-1864," Public Administration, 58 $(1980), 87$. In two cases the result could not be ascertained. With respect to the question of fines, the highest fine recorded was $\$ 25.00$ for employing a boy under the age of 12 who lost two fingers in machine gearing. (Inspectors of Factories, 1890, 32). This was exceptional. Most fines were less than $\$ 5.00$.

${ }^{70}$ Indeed, in one case a prosecution was dismissed because the information was out of time. This led the inspector to call for an amendment to the Act. Inspector of Factories, 1891, 14-5.

"The Ontario Factories Amendment Act, 1895, S.O. 1895 c. 50, s.11.

"For example, in the original Act, section 12 gave the inspectors the authority to issue remedial orders for violations of the provisions regarding sanitation, ventilation and overcrowding, pursuant to regulations made in relation to those subjects. The Ontario Factories' Amendment $A c t, 1889$, s.7, amended that section by adding the words "if any" thereby empowering the inspectors to act in the absence of regulations.
}

${ }^{7}$ R. v. Weir, (1899), 20 C.L.T. 232. 
quate ventilation notwithstanding that section 11(3) only required factories to be ventilated "so far as is reasonably practicable."

A third possible weakness of the Act was that it failed to deal with some of the more significant hazards in the workplace. For example, the Act did not contain specific requirements for the operation of boilers and, although legislation to remedy this defect was regularly introduced, it was vigorously and successfully opposed by employers. However, it is not clear how great an obstacle this posed to the inspectors. They were specifically authorized by the Attorney-General to rely on the general duties section when dealing with matters not falling under more specific clauses, and were successful in the one case they prosecuted under this section. ${ }^{74}$ As well, the Act was reasonably comprehensive and, with the exception of boiler regulation, when problems in the Act were identified, the legislature frequently remedied them.

In sum, inasmuch as some prosecutions were not undertaken because of the external constraints on the inspectors, this does not explain why prosecution was resorted to so infrequently. The explanation is more complex and is hinted at by the following incident. In Hamilton v. Groesbeck, an employers' liability case, the court was called upon to interpret section 15 of Ontario's Factories' Act which imposed an obligation on employers to guard the moving parts of a machine. ${ }^{75}$ The court construed the section narrowly. It its view, it only applied to transitive parts of a machine, not its working parts. In effect, this meant that saw blades did not need to be guarded, only the parts that supplied power to them. On its face, the case suggested that poor legislative drafting combined with judicial hostility would have deterred the inspectors from attempting prosecutions. However a closer examination of the surrounding circumstances undermines that conclusion. First, section 15(1) was subsequently amended by the legislature to overcome this restrictive interpretation. ${ }^{76}$ Second, this case was exceptional. There was no pattern of restrictive judicial interpretations of factory or employer liability legislation." Finally, Inspector Barber favourably commented on the lower court's ruling in his annual report. He treated the decision as a vindication of his own views on the scope of the section, although he claimed that he had advised employers to guard these parts in the past even though they were not legally obliged to do so. ${ }^{8}$ The fact that he publicly expressed his agreement with the court's interpretation is surprising, because the Government had joined the plaintiff's appeal in support of a broader interpretation

\footnotetext{
${ }^{74}$ See, Inspectors of Factories, 1890, 12.

${ }^{75}$ Hamilton v. Groesbeck (1891), 18 O.A.R. 437 aff'g. 19 O.R. 76. For a discussion of the relevance of the Factory Act to an employer liability action see, Tucker, "Employers' Liability," 245-6.

${ }^{76}$ The Factories Amendment Act, 1895, S.O. 1895 c. 50, ss. 3,6.

"Tucker, "Employers' Liability," 241-44.

${ }^{78}$ Inspectors of Factories, 1890, 11-2.
} 
of the Act. More importantly, Barber's comments suggest that his narrow interpretation of the legislation was at least as significant in explaining his behaviour as any constraint externally imposed by the courts, by unfortunate legislative drafting or even by government policy. Certainly this was the TTLC's interpretation of this incident at the time. They referred to Barber's comments on the case in his Report as evidence of his lack of sympathy with the objectives of the law, and emphasized that his views were inconsistent with those of the Government. ${ }^{79}$

In sum, scarce resources were the most substantial external constraint on the inspectors' choice of enforcement strategy. Successful prosecutions require the commitment of resources. Violations had to be detected, evidence collected and given, and counsel instructed. In the face of limited resources, a strategy of enforcement that relied primarily on prosecutions would not have been feasible. Nevertheless, efficiency considerations did not dictate a strategy which virtually abandoned prosectution as a tool of enforcement. Inspectors might have responded differently to the problem of scarce resources in order to maintain a more vigourous prosecutorial component to the enforcement program.

First of all, the Act contained numerous provisions that would have facilitated prosecutions if the inspectors had chosen to initiate them. The inspectors were given substantial powers of investigation and examination by section 25 of the Act. Section 3 provided that a person found on factory premises was deemed to be an employee until the contrary was proved. Further, in 1889, the Act was amended to make a person charged under it a competent and compellable witness. ${ }^{90}$

One way of reducing the costs of detection would have been to develop a network of informers. This was only attempted on a limited scale. Arrangements were made for trade unions to funnel the complaints of their members to the inspectors and, in fact, complaints were received by the inspectors in this manner. ${ }^{81}$ As well, the inspectors received complaints directly from

\footnotetext{
${ }^{79}$ See, The Labour Advocate, 12 June 1891.

${ }^{* 0}$ The Ontario Factories' Amendment Act, 1889, S.O. 1889, c. 42, s.12.

${ }^{81}$ For example, as a result of complaints by the Hamilton Trades and Labour Council that Barber was not enforcing the Act, a meeting between Barber, accompanied by Brown, and representatives of the Hamilton TLC was held at which arrangements were made for the Hamilton TLC to act as the medium of communication between workers and the inspector. See. The Labour Advocate, 2 Oct. 1891. Reference to similar arrangements are to be found in the evidence taken by the Commission on the Sweating System in Canada, 30. As well, the inspectors' correspondence for the years 1898-1900 contains letters from trade unions and councils referring the inspectors to specific matters that had been brought to their attention. Correspondence from these years was fortuitously saved by virtue of the act that in 1901 the Legislative Assembly ordered a return of all correspondence and papers having refrence to the enforcement of the Act. See Ontario, Legislative Assembly, Session Paper 79, (unpublished, 1901), on file at the Public Archives of Ontario, R.G.49, Series 1-7-B-2. (Hereinafter referred to as Inspectors' Correspondence).
} 
employees and other interested persons. ${ }^{12}$ There were, however, significant limitations on this source of information. Although these communications were received in confidence by the inspectors, employees remained fearful of employer retaliation. ${ }^{83}$ Thus, it was not surprising that when inspectors received direct complaints, they were sent anonymously under names such as "One Who Knows," "A.Victim," "A Sufferer," or "An Upholder of Decency." It does not seem, however, that the inspectors actively cultivated a network of informants." Further, although they frequently claimed to speak with employees during their inspections, the fact that they were commonly accompanied by the owner or a superintendent made communication

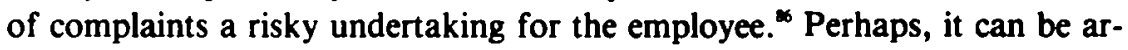
gued that because intimidation made it difficult to rely on informers, it was rational not to adopt a strategy that depended on them. However, such a characterization obscures the class basis of the constraints on the rational. The inequality of power between capital and labour manifested itself in relationships of domination that were enforced by intimidation and exclusion. As Inspector Brown noted in commenting on employer threats: "[P]ity it is that one human being should have the power to determine as to whether another should be permitted to obtain a living or not."

\footnotetext{
${ }^{82}$ Section 29(2) of the Act provided for the posting of the name and address of the inspector at the entrance to the factory, or at such other locations as the inspector directed. However, section 21 exempted factories not employing women and children, as well as some private dwellings, from this requirement. At the behest of the inspectors this exemption was eliminated in 1889. See, The Ontario Factories' Amendment Act, 1889, S.O. 1889, c. 43, s. 8 and Report of Inspectors, 1889,6 . The names of factory inspectors were also published in Labour Day Souvenirs published by local Trades and Labour Councils. For example see Allied Trades and Labour Association, Labour Day Souvenir, 1898, (Ottawa).

${ }^{83}$ For example, Brown noted that he had encountered employers, "who when they hear of complaints being made, do not scruple to express the threat that if they only knew the parties who complained they would be discharged at once." He then commented, "It is not to be wondered at, therefore, that parties having complaints to make should seek to do so through other parties, rather than run the risk of losing their employment." See, Inspectors of Factories, 1890, 21. Similar fears were articulated in the evidence before the Commission on the Sweating System in Canada, 30-3.

The policy of maintaining confidentiality was referred to by Inspector Rocque in Inspectors of Factories, 1888,28 . Rocque also reported that he received no complaints in his first year. Rather than attributing this to fear, he saw it as a sign "that good feeling seemed to exist between the employers and employees."

'Inspectors' Correspondence.

${ }^{85}$ The only reference to the use of such a strategy comes from Inspector Rocque who, feeling frustrated by the difficulty of securing evidence regarding child labour, noted that he had secured the assistance of people in various localities in collecting such information. See, Inspectors of Factories 1899, 17.

${ }^{86}$ See for example, Inspectors of Factories, 1888, 5-6. The practice of inspectors being accompanied by foremen or proprietors was one of the matters raised by the Hamiton TLC in their meetings with Barber in 1891. See The Labour Advocate, 2 Oct. 1891.

"Inspectors of Factories, 1890, 21.
} 
The Act also contained provisions which aimed to reduce the cost of enforcement. Employers were required to maintain various registers, and to give the inspectors notice that they had occupied a factory and that a serious injury had occurred on the premises. ${ }^{88}$ The maintenance of registers of child and female employees and of hours of overtime presumably were intended to make it easier for the inspectors to monitor compliance. Notice of occupation of factories was designed to assist the inspectors in keeping up with changes within their districts, as well as alerting them as to the degree of mechanization in new factories. However, the effectiveness of these devices in reducing the amount of time an inspector would have to spend either to monitor compliance or to locate new factories largely depended on the willingness of employers to comply voluntarily. The fact that failure to comply could result in a prosecution under the Act did not, in itself, pose a serious incentive to comply, since the enforcement of these obligations required the expenditure of the same scarce resources that the provision was designed to conserve. Not surprisingly, inspectors experienced some difficulty with the implementation of these recordinty and notice provisions. ${ }^{89}$

Accident reporting caused inspectors the most problems. Accident reporting can serve a variety of functions in factory regulation. On the one hand, it can provide a data base which can be used to identify widespread hazards, evaluate their seriousness and educate employers about preventative measures they can take. If used in this way, accident reporting is non-threatening. The information obtained is not used as the basis for taking some action aimed directly and exclusively at the reporting employer. On the other hand, accident reporting can be used as a means of detecting violations that resulted in death or serious injury. These violations might be considered particularly suitable for prosecution, or for a remedial order. If used in such a manner, employers would obviously be less inclined to comply voluntarily with the accident reporting requirements.

There can be no doubt that employers initially resisted the accident reporting requirements. For example, in the first year of inspection, only five of the 50 accidents Barber discovered were reported. ${ }^{\circ}$ This could be partly explained by the novelty of the requirement and its limited scope. ${ }^{91}$ However, it could also be explained by the fact that employers initially feared that additional inspections, possible prosecution and an increase in the likelihood

\footnotetext{
${ }^{8 *}$ The Ontario Factories' $A c t, 1884$, ss. 9, 18, 19, 28 and 29.

${ }^{89}$ For example, Barber reported in 1900 that since 1887 he received only 12 notices of occupancy. He discovered new factories by consulting business directories and newspapers. See Inspectors of Factories, 1900, 11.

Inspectors of Factories, 1888, 7.

${ }^{4}$ 'Sections 18 and 19 only required the employer to report serious accidents requiring the worker to be off work for six days which were caused by fire or other specifically mentioned causes. As well, s. 21 created exemptions from the reporting requirement.
} 
of successful employer liability actions by their employees would result from reporting."

The inspectorate tried to achieve better compliance with the reporting requirements in a variety of ways. First, they sought to have the legislation amended to rationalize the requirement and eliminate any confusion that might have existed. Thus in 1889 the Act was amended to limit the scope of the section 21 exemption with respect to factories not employing women and children,, and in 1895 the Act was further amended to require that all serious accidents, however caused, be reported. ${ }^{*}$ Inspectors also assured employers that adverse consequences would not follow from reporting. The preventative purpose of reporting was emphasized by the inspectors, as was the separation between factory regulation and employers' liability litigation." While these measures seem to have improved the regularity of reporting, ${ }^{\infty}$ inspectors continued to discover unreported accidents through other sources. This led to the adoption of a third strategy, the threat of prosecution for non-reporting. ${ }^{97}$ This was a weak threat. If the inspector was late in discovering the non-reporting, prosecution would be precluded because of the expiry of the period for laying informations. ${ }^{*}$ Moreover, in the one instance in which a prosecution for non-reporting was commenced, it failed

\footnotetext{
${ }^{92}$ With regard to the avoidance of prosecutions, non-reporting might result in the accident never coming to the attention of the inspector, or if it did, it might only come after the two or three month limitation period for laying informations had expired. ( s. 38(1)). In employer liability suits, a finding that the injury had been caused by a violation of the Factory Act usually resulted in strict liability. See Tucker, "Employers' Liability," 245-6. Inspectors could be called as witnesses in such actions until 1905 when they were given immunity. See The Statute Law Amendment Act, 1905, S.O. 1905, c. 13, s. 30.

${ }^{93}$ The Ontario Factories' Amendment Act, 1889, s. 8.

${ }^{94}$ The Factories' Amendment Act, 1895, s. 7.

${ }^{95}$ As noted earlier, there were practically no prosecutions arising out of occupationally related deaths or serious injuries. Thus, when Barber explained that the purpose of reporting was to lessen the incidence of accidents (Inspectors of Factories, 1899, 7) employers understood that this did not entail the imposition of sanctions. With respect to employers' liability, Barber reported that he frequently told employers that reporting of accidents had nothing to do with the institution of legal action for damages by employees. (Inspectors of Factories, 1892, 6.) Further reassurance that this separation would be maintained was provided in 1905 when the Act was amended to allow inspectors to refuse to testify with respect to matters arising out of their inspections.

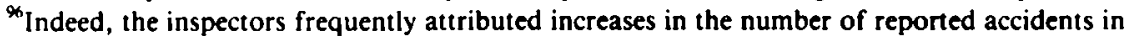
their districts to better reporting. For example, see Inspectors of Factories, 1890, 7.

${ }^{97}$ Failure to report was punishable by a fine of up to $\$ 30.00$. Ontario Factories' $\mathbf{A c t}, \mathbf{s s .} \mathbf{1 8 , 1 9}$. For instances in which prosecutions were threatened see Inspection of Factories, 1892, 26 and Inspection of Factories, 1898, 6, 18.
}

${ }^{98}$ Inspection of Factories, 1893, 13. 
because the injured employee and attending physician testified that she could have returned to work within six days."

In sum, the inspectors could have invested more effort in pursuing strategies designed to maintain a stronger prosecution component to their enforcement program. They chose not to do so. In part, this may be explained as a rational choice made in the face of external constraints, some of which directly reflected the reality of unequal class power. As well, the decision reflected a set of beliefs and assumptions about the causes of unsafe and unhealthy work conditions and the way these could be reduced or eliminated. On the whole, the inspectors believed that education was the best way to achieve compliance. The elements of this worldview need to be reconstructed in order to appreciate their impact on the choice of enforcement strategy.

The inspectors' worldviews included assumptions about the causes of accidents, the social responsibility of employers, the compatibility of labour and capital's interests in occupational health and safety and the special vulnerability of women and children. These assumptions were a critical determinant of the behaviour of the inspectors. Indeed, even if we accepted that the inspectors were motivated solely by their desire to use their scarce resources efficiently, their efficiency calculus was significantly influenced by their outlooks. The salience of ideology in explaining the choice of enforcement strategy is manifested most clearly in the differences that emerged between inspectors Brown and Barber. ${ }^{100}$

The first component of the inspectors' worldviews was their assumptions about accident causation. Barber did not believe that most accidents and injuries were caused by violations of the Act, or by unsafe conditions. In Barber's view, accidents were primarily caused by worker carelessness. For example, in his first report, Inspector Barber cited Mr. Whymper, Superintending Inspector for the Southern Counties of England.

Factory Acts and Inspectors may, should, and, as I now contend, do help to save life and limbs by their efforts to call attention to, and protect dangerous gearing; but they cannot, although indeed they are often credited with the power to do all sorts of things, eradicate people's love for amusement, their inattention, their recklessness. ${ }^{101}$

Barber then noted, "Most accidents are traceable to one or the other of these causes." 102 In a similar vein, Inspector Rocque stated, "I have found belt-

\footnotetext{
99 Employer intimidation seems likely. The employee had part of two fingers cut off and a third injured. The inspector visited her eight days after the accident and was told that she was still in pain and unable to work. Inspectors of Factories, 1893, 20.

${ }^{100}$ Inspector Rocque seems to have shared Barber's worldview, but because be was assigned the less industrialized eastern district his activities did not attract as much attention as Barber's. ${ }^{101}$ Cited in Inspectors of Factories, 1888, 7.

${ }^{102}$ Ibid.
} 
ing, shafting, gearing and moving machinery in all factories in my district, fairly well fenced in and guarded; and I consider that very few accidents would occur, if workmen would exercise more prudence while using or working around machinery in motion." ${ }^{103}$ To the extent that Barber recognized a connection between the labour process and the accident rate, he still tended to blame the worker, or consider the accident unpreventable, presumably on the basis that monotonous or intense work were conditions that workers had to adapt to and not conditions that inspectors should be condemning. ${ }^{104}$

Inspector Brown differed from his colleagues in this regard. He attributed accidents to non-compliance with the Act, and recognized that the employment of young and untrained people, lengthy hours of work on dangerous machinery, piece-rate payment schemes and speeding-up production were frequently the underlying causes of what appeared to others as worker carelessness. ${ }^{105}$ As well, he recognized that accident reports from employers which routinely blamed worker carelessness or disobedience were untrustworthy. ${ }^{106}$ Although Brown may have felt he could not change these conditions, he was prepared to condemn them as the "butcher bill" of increased productive power. ${ }^{107}$

Barber's belief that violations of the Act were not a major cause of occupational deaths and injuries contributed to, and strengthened a second belief: that the overwhelming majority of employers were willing to cooperate with the inspector in eliminating violations or hazards that were pointed out to them. He and Rocque continuously repeated the observation that they were cordially received by employers who expressed a desire to conform to the Act and who took a real interest in the welfare of their employees. ${ }^{108}$ Regret was expressed when employers resisted recommendations that involved substantial expense, but this did not detract from the overall positive perception of employer cooperation. ${ }^{109}$ Employers who exhibited this positive attitude merited understanding from the inspectors. They were not to be treated as potential offenders who had to be carefully monitored in order to detect deviant behaviour, but rather were to be educated and assisted in their

\footnotetext{
${ }^{103}$ Ibid., 29.

${ }^{104}$ Inspectors of Factories, 1897, 8-9.

${ }^{105}$ Inspectors of Factories, 1890, 18 (young people); Inspectors of Factories, 1891, 14 (noncompliance); Inspectors of Factories, 1892, 14 (long hours); Inspectors of Factories, 1888, 21 (piece-work) and Inspectors of Factories, 1899, 15 (speed-ups).

${ }^{100}$ Inspectors of Factories, 1895, 15.

${ }^{107}$ Inspectors of Factories, $1899,16$.

${ }^{108}$ For example, see, Inspectors of Factories, 1889, 8.

${ }^{109}$ For example, Inspector Barber notes in his report for 1891 that " 1 have been in all cases cordially received by employers, who, with very rare exceptions, show every disposition to conform to the requirements of the Factories' Act, so long as no great outlay of money is involved in making the changes necessary to accomplish that object." Inspectors of Factories, 1891, 5. This observation does not detract from the positive tone of the report.
} 
efforts to conform to the law. ${ }^{110}$ Given this view of the social responsibility of employers, "' it made perfect sense to regard one of the primary functions of the inspector as an educator who provided information to employers on safety technology and plant design. ${ }^{112}$ Increasingly, the inspectors' reports came to be filled with information and advice of this nature.

Of course, not all employers fell into the category of the socially responsible. The inspectors also reported the existence of a small minority of employers who regarded the Act and the inspectors as an unwarranted intrusion into their private affairs. Fortunately, this minority was seen to be decreasing in size as the inspectors succeeded in educating them and gaining their confidence by demonstrating their reasonableness. Inspector Rocque described this approach aptly:

When the Act came in operation the employers mistrusted the Inspectors, and were so prejudiced against them and the Act that they considered it as an interference with their business and liberty as citizens; but by using much discretion and enforcing the provisions of the Act gradually and in such cases only which seemed, at the time, reasonable to the employer the Inspectors have succeeded in divesting him of all prejudices; and in my district I must say that I have now reached a point where I can secure the co-operation of mostly all employers and many overseers, not only in the carrying out of all suggestions made in accordance with the Act, but also any propositions to better the conditions of the employees."

In a world in which employers are cooperative, or can be easily won over, a persuasive strategy of enforcement is eminently reasonable. Prosecutorial activity would only serve to destroy the trust upon which the cooperative relationship is built. It was on the basis of these perceptions that the inspectors came to see prosecution as an option to be resorted to only in exceptional cases. This approach to prosecution was most clearly articulated by Inspector Barber:

Though I have during the year met with many cases where some slight violations of the Act have occurred, through not attending to some of its provisions, still I have not met with

${ }^{110}$ See, Inspectors of Factories, 1889, 7, where Inspector Barber recites the following speech of Mr. Whymper, H. M. Superintending Inspector of Factories and Workshops, with approval.

[B]y some to carry out the Factory Act is thought to mean that every place should be visited at short regular intervals, without reference to the expediency of the visit, and that every district should be, as it were, patrolled by Inspectors; that, in a word, no single irregularity, however rare or isolated, should take place without approximate certainty of detection and punishment. In the eyes of others, to carry out the Act means to prevent these rare irregularities being multiplied to an extent which would involve hardship or injury to the protected persons, and it is this meaning which I, for one, accept.

'"Hawkins' found that pollution enforcement officers in modern England also made the assumption that most dischargers were socially responsible. See Hawkins, Environment and Enforcement (Oxford 1984), 110.

${ }^{112}$ For a similar view of how factory inspectors defined their role see Jones, "An Inspector Calls: Health and Safety at Work in Inter-War Britain," in Weindling, ed., The Social History of Occupational Health (London, 1985), 223.

${ }^{113}$ Inspectors of Factories, 1898, 23. 
any such that I considered as intentional, but rather an oversight. I might more particularly refer to the non-reporting of accidents, and occasionally employing a child without first procuring a certificate of age. I have not thought it necessary to lay these matters before you and recommend prosecutions, believing that in time as employers become more familiar with all the provisions of the Act, the inspector will have very little to complain of. Prosecutions, I consider, should be resorted to only when violations seem wilful, or through indifference, and where other means fail to have the law observed. ${ }^{14}$

The belief that most accidents were either unavoidable or the result of worker carelessness, and that most employers were good citizens who were prepared to cooperate with the inspectors meshed with, and reinforced a third component of the inspectors' worldview: that health and safety in the workplace was not an issue on which there was, or ought to be, conflict between employers and workers. Factory regulation was seen to be mutually beneficial to employers and employees alike. Of course, the inspectors realized that this view was not self-evidently true, particularly to employers, and that one of their tasks was to convert the non-believers. We have already seen that the inspectors undertook to demonstrate to employers that they would be reasonable in exercising their discretionary powers under the Act. One aspect of that reasonableness was the willingness of the inspectors to be sensitive to the general economic climate. For example, during the recession/depression of the early 1890 s Inspector Barber noted, "In making my inspections I do not overlook the unsatisfactory state of trade in many industries, and in some cases have passed by some alterations required that I would not have done had trade been more prosperous, as regards these factories." "115 Indeed, even in good times, the cost of remedial action, such as the introduction of fans, was taken into account by the inspectors in exercising their discretion as to what constituted compliance with the Act. ${ }^{116}$

Of course, the inspectors were not always willing to defer to employer arguments about costs. Indeed, inspectors frequently argued that compliance was in the economic self-interest of employers because the long term economic benefits flowing from compliance outweighed its immediate costs. For example, in his report for 1890 , Inspector Barber provided a general defence of factory legislation which concluded with a quote from the English Royal Commission of 1875 on the impact of regulation.

We have no reason to believe that the legislation which has been productive of such marked

\footnotetext{
114Inspectors of Factories, 1891, 9-10.

11'Inspectors of Factories, 1891, 5. A similar sensitivity to the economic conditions was expressed by Margaret Carlyle in 1897. "Though actuated with a desire to enforce all laws by which we are governed for the benefit and protection of the labouring classes, yet, in view of the depressed condition of business of all kinds in the first part of the year, it was necessary to be very careful not to make demands that were not absolutely necessary." Inspectors of Factories, $1897,18$.

${ }^{116}$ Inspectors of Factories, 1894, 9.
} 
benefit to the operatives employed, has caused any serious loss to the industries to which it has been applied. On the contrary, the progress of manufacture has apparently been entirely unimpeded by the Factory Acts; and there are but few, even among employers, who would now wish to repeal the main provisions of the Acts, or would deny the benefit which has resulted from them. ${ }^{117}$

The gospel that "safety pays" was preached by the inspectors. Improved conditions and a working day that did not exceed the legal limits would increase worker productivity and firm profitability. As well, employers were told of the general benefit of having a satisfied workforce, and that the Act would relieve competitive pressure generated by employers who "are not abreast of the times." "18

The inspectors also believed that there was no fundamental conflict of interest between workers and their employers over health and safety. Indeed, they believed that the industrial system operated to the mutual benefit of employers and employees in all areas. As such, it was expected that in normal times employees would be as willing to be reasonable in their demands as were the inspectors, since their interests were not fundamentally different from those of their employers. Therefore, when employees complained about violations of the Act or the failure of the inspector to intervene on their behalf, the difficulty was frequently attributed to labour unrest having nothing to do with health and safety.

The best example of this attitude arose out of a controversy in Brantford over a demand for ventilation fans. On 13 June, 1898, Mr. F. Mather, Secretary of the Brantford Trades and Labour Council, wrote to the AttorneyGeneral complaining that, despite several complaints to the inspector, no action had been taken to require the installation of fans in a number of factories in the town. The matter was referred to the Minister of Agriculture who forwarded the complaint to Inspector Barber. On 16 June 1898 Barber wrote to the Minister explaining the problem as one in which "there is an animus against the Company because they do not recognize the Union and the Union wants to cause them annoyance and to get my help." No action was taken. A further complaint was sent to the Minister on 19 October, 1899. After further investigation the Minister responded on 10 November, stating that, "I do not think it advisable to unduly press the matter at the present time, as I have no doubt the firm will duly comply with the requirements of the Act as soon as they can do so without serious injury to business."

\footnotetext{
${ }^{117}$ Inspectors of Factories, $1890,15$.

${ }^{118}$ Inspectors of Factories, 1892, 5.
} 
Upon further complaint, the Minister finally ordered Inspector Barber to take action on 9 March $1900 .{ }^{119}$

Just as Inspector Brown disagreed with his colleagues over the cause of accidents, so too he disagreed with them over the other components of their world view. Although he advised employers in his first report that, "I have endeavoured, in enforcing the Act, to put a liberal construction upon its requirements, not asking to take undue advantage of any non-conformity not in wilful violation of the Act," and noted the willingness of most employers to comply, he also recognized that employers and employees did not necessarily share a common interest. This was not seen to be just a function of some ill informed employers who "appear to be indifferent to their [employees'] welfare," but rather the result of an industrial system in which "production and distribution are carried on primarily with a view to make money for individuals and firms of an employing class, and without regard to the interests of the workers engaged in production and distribution...."

The fourth component of the inspectors' world views was their attitude toward women and children. In this regard, there were no significant differences between Barber and Brown, or for that matter, between Carlyle and her male colleagues. All were equally vociferous in their denunciations of the evils of child labour, although Brown was somewhat more sensitive to the harsh economic realities that sometimes led working class parents to send their children into the factory. ${ }^{121}$ They also all claimed that the laws in this regard were vigorously enforced. ${ }^{122}$

With regard to female labour, the male inspectors generally reported on their enforcement of provisions designed to protect female labour with little

\footnotetext{
${ }^{119}$ See, Inspectors' Correspondence. In commenting on these events in his annual report Inspector Barber noted, "I wish to do justice to the workers and the employers, and sometimes I reach a deadlock.... When there is a good understanding between the polishers' union and the employer there are few complaints, but it is quite different when all is not harmonious. All complaints with respect to ventilation and dust have been investigated, and the cause of complaint has been, or is being removed as far as possible in most cases." Inspectors of Factories, 1899, 3-4.

${ }^{120}$ Inspectors of Factories, $1893,15$.

${ }^{121}$ Inspectors of Factories, 1898, 15.

${ }^{122}$ An equal number of parents and employers were prosecuted for violations of the child labour laws. The following comment of Inspector Carlyle is typical.

The welfare of the child cannot be sacrificed to the short-sighted demands of parents, who, for their own apparent benefit, would doom their children to a life of toil and ignorance. My view of the duty, as it regards the enforcement of this, or any other law, is, that while good judgment and discretion ought always to be employed, the whole fabric of legal protection to child labour could be undermined if the enforcement of these laws were left to discretion of the Inspector.

See Inspectors of Factories, 1899, 22.
} 
or no commentary. ${ }^{123}$ There were some expressions of special concern arising from a perceived female disposition to panic in emergencies, ${ }^{124}$ but on the whole, the rhetoric of the male inspectors was milder than that of many of the reformers who had called for legislation in the first place. The entry of women in fields that had previously been exclusively male was noted with some mild reservation, but certainly no great alarm. ${ }^{125}$

Of course, much of the male inspectors' responsibility for the enforcement of provisions relating exclusively to women was alleviated by the appointment of Margaret Carlyle in 1895 as Female Inspector of Factories. ${ }^{126}$ Pursuant to the Order-in-Council appointing her, except as regards to provisions relating to machine fencing and fire safety, she was given complete jurisdiction over factories employing female labour only, and shared jurisdiction over matters relating to the employment of women and children in mixed settings. ${ }^{127}$ Not surprisingly, she was paid half as much as the male inspectors. ${ }^{128}$ The appointment of a female inspector was widely supported on the grounds that it would facilitate the enforcement of those provisions designed principally for the protection of female employees. ${ }^{129}$

\footnotetext{
${ }^{123}$ Inspector Rocque reflected the prevailing wisdom when he reported, "The Act is also calculated to protect society in providing such regulations as would guard the morals where so many persons of different sexes are employed in the same workrooms...." (Inspectors of Factories, 1893, 17).

${ }^{124}$ See Inspectors of Factories, 1895, 8 (Barber).

${ }^{125}$ Inspector Barber noted that he could not, in his own mind, accept all the justifications offered for having women perform work which ten or fifteen years ago had been considered proper for men only (Inspectors of Factories, 1891, 7). Inspector Brown, in the course of condemning the sweating system in the clothing trades, noted that wives and daughters of workmen who take out work from clothing houses "to eke out the wages of a husband, or father, or it may be to get a little "pin money" " drive down the wages of those who depend on their jobs for a living, (Inspectors of Factories, 1893, 15). Brown also expressed discomfort with having to deal with "female employers who are of a masculine turn." (Inspectors of Factories, $1891,15)$.

${ }^{126}$ Carlyle had been employed in manufacturing establishments in Glasgow prior to emigrating to Canada. Prior to her appointment she was in business for herself in Toronto. As well, she was an active suffragist. See Bacchi, Liberation Deferred? (Toronto 1983) 29, 41 and Morgan, ed., The Canadian Men and Women of The Time, 2nd ed., (Toronto 1912), 200.

${ }^{122}$ Public Archives of Ontario, R.G.3, O.C. 32/360, Order-in-Council, 5 July, 1895.

${ }^{128}$ Even after nearly twenty years' service, Carlyle was paid less than the most junior male factory inspector. See Ontario. Public Accounts, Sessional Paper 1, (Toronto 1913-14). Cariyle advocated equalizing the wages of men and women as a solution to the downward pressure on wages that resulted whenever women began to perform work previously done exclusively by men. See Inspectors of Factories, 1898, 31. Obviously, she did not achieve this goal for herself. ${ }^{129} \mathrm{As}$ one commentator noted at the time, "There must be women inspectors where there are women employees. The greatest trials and hardships of a factory women's life can be told only to one of her own sex." Annie MacLean, "Factory Legislation for Women in Canada," American Journal of Sociology, 5 (1899), 172, 180. Both Barber and Brown commented on the fact that Carlyle had received complaints that otherwise would not have surfaced. Inspectors of Factories, $1895,9,13$.
} 
Given her mandate it is not surprising that Carlyle focused on matters such as hours of work, ventilation and sanitation, including the provision of separate lavatories for men and women. However, her general world view was more consistent with Barber's than Brown's, including her view that workers were frequently responsible for their own misfortune. ${ }^{130}$ With respect to women, she vigorously defended the appropriateness of their entry into the public sphere of industrial production. She defended the honourable position of "factory girls" 131 and promoted conditions conducive to its protection. For example, she recommended that young girls be supervised by women overseers, ${ }^{132}$ and upbraided foremen for using abusive language. ${ }^{133}$ In general, her worldview seems very much in line with the "maternal feminism" of other middle class reformers of the period. ${ }^{134}$

What impact, if any, did these values and assumptions have on the enforcement of the inspectors? The most striking pattern is that 29 of the 35 charges prosecuted related to the protection of child and female labour. On its face this suggests that when it came to enforcing these provisions, the inspectors' belief in the special vuinerability of women and children, and the immorality of exploiting that vulnerability, significantly influenced their will-

\footnotetext{
${ }^{130}$ For example, Carlyle claimed that poor sanitary conditions were mostly the fault of the oper-
} atives themselves.

Employees often mis-use the best provisions made for their comfort and welfare. They destroy ruthlessly the most expensive plumbing, and litter and soil rooms uselessly. On the other hand there are places where women of refined habits, and high sense of order, carry those qualities into their working surroundings.

Inspectors of Factories, 1898, 28.

131 A very large percentage of our factory girls are beautiful types of Christian devotion and fine womanly feeling. I am sure you will find as large a number of generous selfsacrificing sisters and daughters among mill help as among any other class in the world. There is honor in every right walk of industry, whether it is weaving fabrics or selling the product from the counter.

Inspectors of Factories, 1896, 24.

${ }^{122}$ Inspectors of Factories, 1899, 26.

${ }^{133}$ Inspectors of Factories, 1900,21 . ("I fail to understand how anyone calling himself a man could be guilty of such conduct.")

${ }^{134}$ See Linda Kealey ed., A Not Unreasonable Claim (Toronto 1979), and especially Wayne Roberts, " 'Rocking the Cradle for the World': The New Woman and Maternal Feminism, Toronto, 1877-1914," Ibid., 15. A classic example of the rhetoric of maternal feminism can be found in the speech of Cora Stuchfield, a woman factory inspector from Pennsylvania, given before the tenth annual convention of International Association of Factory Inspectors held in Toronto in 1896 , and attended by Carlyle.

In every woman's soul is a desire to benefit her fellow-beings, and she does it whenever a chance is afforded her. This great quality of heart has been a mighty factor in our civilization, and where could woman find a more unlimited or better field to aid in up. lifting and reducing the sufferings of toilers in the factories?

A true woman carries with her an atmosphere which makes itself felt....

International Association of Factory Inspectors, Convention Proceedings (1896), 75-6. 
ingness to stigmatize violators by prosecuting them. The time for negotiated compliance to take place was reduced. However, equally striking is the fact that 27 out of these 29 charges were initiated by Brown. This suggests that even though the inspectors agreed on the need for special protection, only Brown saw prosecution as an appropriate means of providing it, despite the fact that he faced the same external constraints as they did. This difference can perhaps best be explained on the basis of his understanding of the motivation of employers and the limits of persuasion as an enforcement strategy. Further, it suggests that instrumental rationality is not a sufficient explanation of enforcement behaviour. Rationality cannot be divorced from the assumptions and values brought to bear in evaluating the problem to be resolved.

\section{Constructing the Meaning of Compliance}

Beyond the question of the choice of enforcement strategy lies the question of what significance, if any, did the differences between Brown and Barber have on the levels of risk to which workers were exposed. Were the workers in Brown's district any better off than were the workers in Barber's district? The accidental injury and death data that we have for this period is probably too crude to allow meaningful comparisons to be made and I have not attempted to do so. ${ }^{135}$

Another way of trying to assess the impact of enforcement strategies is by comparing the way in which different inspectors constructed the meaning of compliance with the Act. An understanding of this is critically important for evaluating enforcement behaviour and strategies. For example, if compliance was constructed in such a way so that few, if any, serious hazards were found to be unlawful, then it would make little difference whether we had a negotiated compliance model or a prosecution model. Both would be equally passive and ineffective in improving workplace health and safety. We must, therefore, look beyond the choice of enforcement strategy and also examine the standard of compliance that was selected by the inspectors. In particular, it will be useful to identify any differences in the way inspectors Barber and Brown constructed the meaning of compliance, and relate that to the differences we have already identified in their worldviews and their enforcement strategies.

The meaning of compliance was, in many instances, far from clear on the face of the statute. We have already noted that the open-ended language used in many sections of the Act gave the inspectors a significant amount

\footnotetext{
${ }^{135}$ For a study that attempts to measure the impact of different enforcement strategies on accidental rates in nineteenth century England see Bartrip \& Fenn, "The Administration of Safety: The Enforcement Policy of the Early Inspectorate, 1844-1864," Public Administration, 58 (1980), 87.
} 
of discretion in determining the meaning of compliance. Further, manufacturers expressed great fears that this discretion might be exercised to their detriment by inspectors sympathetic to the cause of labour. There is not much direct evidence on how Barber and Brown interpreted the Act and its requirements, and so any conclusions must remain qualified. Nevertheless, I think it is fair to surmise that, on the whole, the inspectors defined compliance in a way that did not require employers to incur substantial costs in order to alter their technology or work practices. Moreover, as between Brown and Barber, Brown was the more demanding.

We have already seen that both the government and the inspectors were willing to consider profits as a relevant criteria in enforcing the Act. This was illustrated by Barber's comment on an amendment to the Act that enhanced the discretionary power of the inspectors.

Of course this leaves a great deal to the judgment of the inspectors, and may in some applications of it be the means of a difference of opinion arising between them and employers; but I am sure that when such differences do arise, and the employers can give good reasons why such dangers should not be protected, the inspectors will be reasonable, for they understand it to be the wish of the Government that the Factories' Act shall be enforced in an efficient manner, with as little friction and annoyance as possible. ${ }^{136}$

To the extent that profitability was incorporated into the criteria of what was reasonably necessary for the safety of workers, it would lead to a construction of the meaning of compliance which would not be terribly burdensome to employers.

Another reason for hypothesizing that compliance came to be constructed in a way that was favourable to employers arises from a sociological perspective on the interaction between inspectors and regulatees. It has been noted that there is a tendency for inspectors to become more sympathetic towards employers and their compliance problems after they have spent time in the field. ${ }^{137}$ In part this may be explained by a desire to avoid the unpleasantness that is likely to occur in the face of a continuing adversarial relationship. The nineteenth century factory inspectors frequently expressed their relief that nothing of an unpleasant nature had occurred in the course of carrying out their duties. Another cause of this phenomenon relates to the symbolic dimensions of authority. Inspectors not only wanted to avoid unpleasantness; they wanted the authority conferred upon them to be respected. This would be particularly true in the context of a situation in which that authority was to be exercised with regard to persons who would otherwise be considered to have a higher socio-economic status. The effect of this dynamic suggests that in negotiating the meaning of compliance, an employer

\footnotetext{
${ }^{136}$ Inspectors of Factories, $1895,7$.

${ }^{137}$ For contemporary evidence see Kelman, Regulating America, Regulating Sweden (Cambridge 1981), 184.
} 
who recognized the inspector's authority by indicating a willingness to take some action in the future in response to the inspectors concerns would be found to be in compliance with the Act by the inspector. ${ }^{138}$

The effect of these factors on the standard of compliance imposed by the inspectors is uncertain. The inspectors indicated that in negotiating compliance with employers, they required improvements to be made. They also claimed that significant improvements were taking place as a result of their efforts. However, it is unclear how much weight we should give to the inspectors' self-evaluations, given the obvious incentives to promote a positive view of their work. For example, despite the continual assurance that progress was being made, the same kinds of problems re-appeared year after year. Frequently it is difficult to determine whether an inspector is telling us about actual changes, or is reporting on the extent to which the employer has indicated a willingness to change in the future. The following excerpt from a report by Barber typifies this ambiguity.

[I] am pleased to be able to report that I have been in all cases cordially received by employers, who with very rare exceptions, show every disposition to conform to the requirements of the Factories' Act, so long as no great outlay of money is involved in making the changes necessary to accomplish that object. . .

The Inspector has at times to make suggestions that are not at all welcomed by the employ$e r$, and it is gratifying to me to be able to say that in the pursuance of my duties this year, nothing of an unpleasant nature has occurred with any of the persons among whom my duties called me, and, further, I have every reason to believe that most of my suggestions have been carried out, so far as time for doing so would permit, for some of them are of recent date. ${ }^{139}$

Further evidence that the operative meaning of compliance generally favoured employers comes from the fact that while the labour movement regularly complained about inadequate enforcement, there do not appear to be any complaints from business groups about excessively strict enforcement. Indeed, business groups sometimes praised the inspectors' behaviour. At the annual convention of the CMA held in 1888 Secretary Nicholls reported that, "the inspectors under the Factory Act have so far acted impartially and that, whilst requiring that the provisions of the statute be respected, have not caused undue friction by arbitrary interpretations of such provisions." ${ }^{140}$ Indeed, the following year Nicholls pointed to the Act's implementation as a vindication of the Association's decision not to oppose the measure. ${ }^{141}$ The only other time $C M$ discussed factory inspection was

\footnotetext{
${ }^{138}$ This point is made by Hawkins in a contemporary study of pollution inspectors. "What the polluter actually does by way of compliance is probably no more important for the field officers than that some sign of compliance is made, a sign of respect for their ultimate authority symbolizing a willingness to comply." Hawkins, "Bargain and Bluff," Law \& Politics Quarterly. 5 (1983), 35, 56.

${ }_{139}$ Inspectors of Factories, 1891, 5-6.

${ }^{140} \mathrm{CM}, 17$ Feb. 1888.

${ }^{141} C M, 15$ March 1889.
} 
when they came to the defence of Inspector Barber who had incurred the displeasure of the TTLC for consenting to an alteration of the hours of work that was not permitted by the statute. ${ }^{142}$

Notwithstanding that the above evidence suggests that, in general, the meaning of compliance was constructed in a way that did not threaten to disrupt the employers' business, there is evidence to suggest that Brown was somewhat more exacting in his demands on employers than were his colleagues. This difference is found most clearly in a controversy over ventilation that erupted in the City of Toronto in 1899. On 24 October, 1899, the Minister received a letter from D. J. O'Donoghue, Secretary, Legislative Committee, Toronto Trades and Labour Council, complaining of conditions in a number of factories in Toronto. Some of those factories were in Brown's district, others were in Barber's. The complaints were forwarded to the appropriate inspector. Barber reported on 3 November.

In no shop is the air as good as that outside and I suppose men working in such places ten hours daily do feel a small proportion of dust-more than one making an occasional visit. But in no factory visited did I find such a condition existing that would cause me to take action without having a complaint first. Some of the employers I have spoken with expressed their readiness to provide blowers if ordered to, but denied the need of them, and blamed the Polishers' Union for the present agitation.

Brown reported on 21 November.

Hitherto in the past, where only one machine has been in operation principally for buffing, I have not insisted on a fan being installed for the removal of dust.

Having had an interview with representatives of the Polishers and Buffers Union with regard to the installation of fans in places where only one machine is in operation, they represent that one man using a machine where dust is generated suffers in health from inhaling such dust and his health should be protected as well as that of the workers where more than one machine is in use.

Brown recommended that fans should be installed, and sought a directive of general application from the Minister on this point so as to assure uniformity in the enforcement of the Act. As well, he arranged to have Peter Bryce, Secretary, Provincial Board of Health, inspect the factories in question. Based on his inspection and a review of the medical literature, which even then recognized occupational disease from metallic dust, Bryce supported Brown's recommendation. The Minister referred the matter back to the inspectors for a common recommendation. None was forthcoming. In separate letters both dated 8 January 1900, Brown recommended that a directive be issued to the inspectors requiring the installation of fans, while Barber recommended that the matter should be left to the discretion of each inspector.

The paper trail runs cold at this point and it remains unclear how the controversy was resolved. However, the incident clearly illustrates how the

\footnotetext{
${ }^{142}$ The matter involved the lengthening of the weekday working day in exchange for a shorter workday on Saturdays. See CM, 2 Jan. 1891. For labour's views see Labour Advocate, 26 Dec. 1890, and 23 Jan. and 13 Feb. 1891.
} 
different assumptions and values of Barber and Brown influenced not just their choices of enforcement strategy, but their appreciation of the standards that employers were required to meet in order to bring themselves into compliance with the Act. Although there is no inherent reason why a more prosecutorial strategy would be accompanied by more exacting standards, our analysis suggests that the same factors that lead to one, also lead to the other. This further points to the weakness of an analysis of enforcement that focuses too strongly on the efficient allocation of scarce resources in the face of external constraints. More prominence must be given to the ways in which the mission of the enforcement agency and its officials are constructed.

II

Conclusion

THE ENACTMENT OF FACTORY legislation in the 1880 s can be viewed as a concession to the demand of workers that the state be empowered to insure that minimally safe and healthy workplace conditions were provided by employers. The ability of workers to obtain concessions was not just a function of their level of organization and ideological orientation, but was also aided by presence of middle class reformers concerned about the impact of industrial capitalism on women and children who were drawn into factory work, and by manufacturers who were resigned to having factory legislation as a cost of obtaining the political support they needed for economic policies designed to promote local industry. However, the goals that these groups sought to achieve through factory legislation were contradictory. In particular, employer concerns over their profitability and freedom to control and direct the labour process were, at least potentially, in conflict with worker demands for safer and healthier work environments. The legislation itself did not specify how these contradictory pressures were to be resolved, leaving it instead to the implementation process. The critical importance of the implementation process was recognized by both workers and manufacturers from the time factory legislation was first proposed, and it was in this process that workers suffered their most serious defeats.

There can be no doubt that, from the outset, the resources devoted to enforcement were woefully inadequate. This was an unavoidable reality for the inspectors and obviously limited their options in developing an enforcement strategy. As well, they faced other constraints including government attitudes and the difficulties of detecting violations and gathering evidence that could be used to prosecute employers. However, these constraints were either a direct function of, or significantly exacerbated by, the structural inequality of class power which manifested itself in the political and economic spheres. Thus, even if it could be maintained that the decision to adopt a 
negotiated compliance strategy was based entirely on the determination that it made the most efficient use of resources, the significance of class power on the ability of the state to regulate against the interests of capital would still not be negated. Furthermore, scarce resources and other external constraints limited the effectiveness of any strategy of enforcement, even if the most efficient one was selected.

It is also not clear that, even in the face of the problem of scarce resources and other constraints, efficiency dictated the virtual abandonment of prosecution as a weapon in the inspectors' armory. A number of recent writers on enforcement have suggested that an efficient enforcement strategy requires a mix of tactics, including prosecution for firms that cheat or are noncooperative. ${ }^{143}$ On the assumption that not all Ontario employers were angels, the virtual absence of prosecutions raises a serious doubt that the inspectors chose the most efficient strategy.

I have also argued that the selection of an enforcement strategy by the inspectors cannot fully be understood without recognizing the significance of their worldviews. The predominant view was that worker carelessness was the most important cause of accidents; that employers were socially responsible; that there was no fundamental incompatibility between the interests of labour and capital over factory regulation; and that women, and particularly children, required special protection. From this perspective, educating workers and employers on occupational health and safety appeared to be a reasonable approach. As well, with the exception of Brown, the inspectors accepted the intensification of the labour process and expected workers to adapt to it. They knew, however, that these changes did result in more workplace injuries, but viewed these an unpreventable. Thus, it seems, they accepted the fundamental legitimacy of an industrial capitalist system, and saw the role of the state and its agents as one of reacting to, and limiting, the excesses of that system, not controlling its normal consequences. The excesses were seen to relate almost exclusively to its failure to provide special protection to women and children, and with respect to children, working class parents were seen to be at least as guilty as the manufacturers.

This worldview was not uniformly shared by the first factory inspectors in Ontario, but it is clear that Brown was the exception. He represented a continuing link between working class politics and ideology of the 1880's and the implementation of the factory legislation it promoted. The triumph of "Barbarism" can be understood in part as a consequence of the triumph of industrial capitalism over the alternatives espoused by groups such as the Knights of Labour. Although this triumph was never total, it left in its path a pattern of state interventions which succeeded in mediating and contain-

\footnotetext{
${ }^{143}$ For example, see Scholz, "Voluntary Compliance and Regulatory Enforcement," Law \& Politics Quarterly 6 (1984) 385 and Braithewaite, To Punish or Persuade (Albany 1985), 119-148.
} 
ing class conflict through relatively minor legislative concessions that were administered compatibly with the industrial capitalist order. ${ }^{14}$

The choice of a negotiated compliance model of enforcement, in conjunction with the construction of the meaning of compliance which accept-ed many risks commonly present in workplaces resulted in the resolution of the ambiguities present in the legislation in ways that were compatible with employers' interests in profitability and the maintenance of control over the labour process. This suggests that the compliance or persuasion model of enforcement adopted by the majority of inspectors did not, in practice, turn out to be much of an enforcement model at all. Rather, it closely resembled a capture model in which the agency and its officials stop trying to alter the behaviour of the regulated. ${ }^{145}$

The pattern of enforcement that was established in nineteenth-century Ontario was, by no means, unique to this Province or, indeed, to this period. It was literally the "conventional" wisdom of the time, and still prevails today. ${ }^{146}$ An understanding of the origins of these views may not explain their persistence, but it does suggest that they are deeply rooted in, and determined by the structural inequality between labour and capital that is typical of industrial capitalist social formations. ${ }^{167}$

\section{I wish to thank my research assistant Nancy Kleer whose enthusiasm and resourcefulness greatly contributed to this paper. I would also like to thank Harry Glasbeek, Neil Gunningham, Craig Heron and Andrew Ranachan for their comments on earlier drafts.}

\footnotetext{
${ }^{144}$ For other instances of this pattern see, MacCallum, "Keeping Women in Their Place: The Minimum Wage in Canada, 1910-25," Labour/Le Travail, 17 (1986), 29, and Craven, Impartial Umpire.

${ }^{145}$ I am unsure what Hawkins had in mind when he wrote, "To regard a compliance strategy of enforcement at field level, or the formulation of prosecution policy at headquarters as symptomatic of the capture of the regulators misses the point. The practice of regulatory enforcement expresses an identity of moral values which transcends the regulator-regulated relationship." Supra note 000, 207. If all he meant is that the regulators and the regulated share common values formed outside of the relationship, I find the statement unobjectionable, although incomplete. Kelman's Regulating America suggests that values alter as a result of the relationship. However, in a context in which the applicable norms are a matter of dissensus, and in which the interests of labour and capital are in conflict, the existence of an identity of values between the inspectorate and employers does not transcend the notion of capture; rather, it becomes indicative of its establishment.

${ }^{146}$ The international dimensions of this dominant worldview can be seen in Barber's citation of English inspectors in support of his views. These views were routinely presented at the conventions of the International Association of Factory Inspectors. For a particularly good example see the speech of Rufus Wade, Chief Inspector of Massachusetts, in International Association of Factory Inspectors, Convention Proceedings (1896), 32. That convention was held in Toronto and attended by the Ontario inspectors.
}

With respect to subsequent periods, preliminary research into the period between 1900 and 1914 indicates that negotiated compliance became the exclusive model of enforcement, and that not- 
withstanding the inspectors' glowing self-evaluations, the accident and injury rate rose quite dramatically. For a critical analysis of the current state of occupational health and safety regulation in Ontario see Tucker, "The Persistence of Market Regulation of Occupational Health and Safety: The Stillbirth of Voluntarism," in England, ed., Essays in Labour Relations Law (Toronto 1985), 219. The most recent affirmation of this approach is to be found in McKenzie and Laskin, Report on the Administration of the Occupational Health and Safety Act (Toronto 1987) where the authors dismiss the view that workers and employers have a conflict over health and safety, and that the imbalance of power between them must be redressed, with the assertion that, "In the view of this study, these assumptions are inaccurate." (Vol. I, C. 2, p. 9).

${ }^{147}$ For an interesting discussion of the impact of historical patterns on current practices see Carson, "Hostages of History: Some Aspects of the Occupational Health and Safety Debate in Historical Perspective," in Creighton \& Gunningham, eds., The Industrial Relations of Occupational Health and Safety (Sydney 1985) 60.

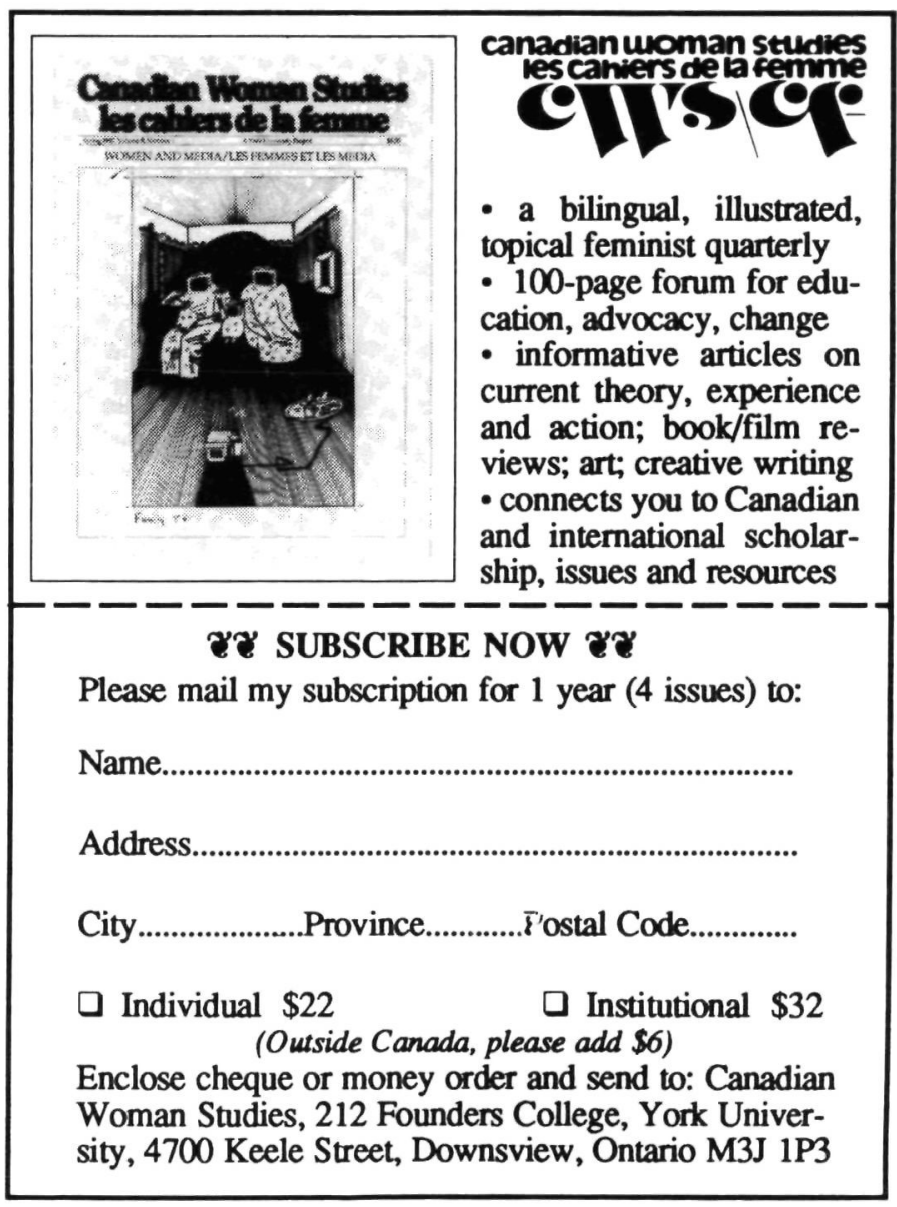




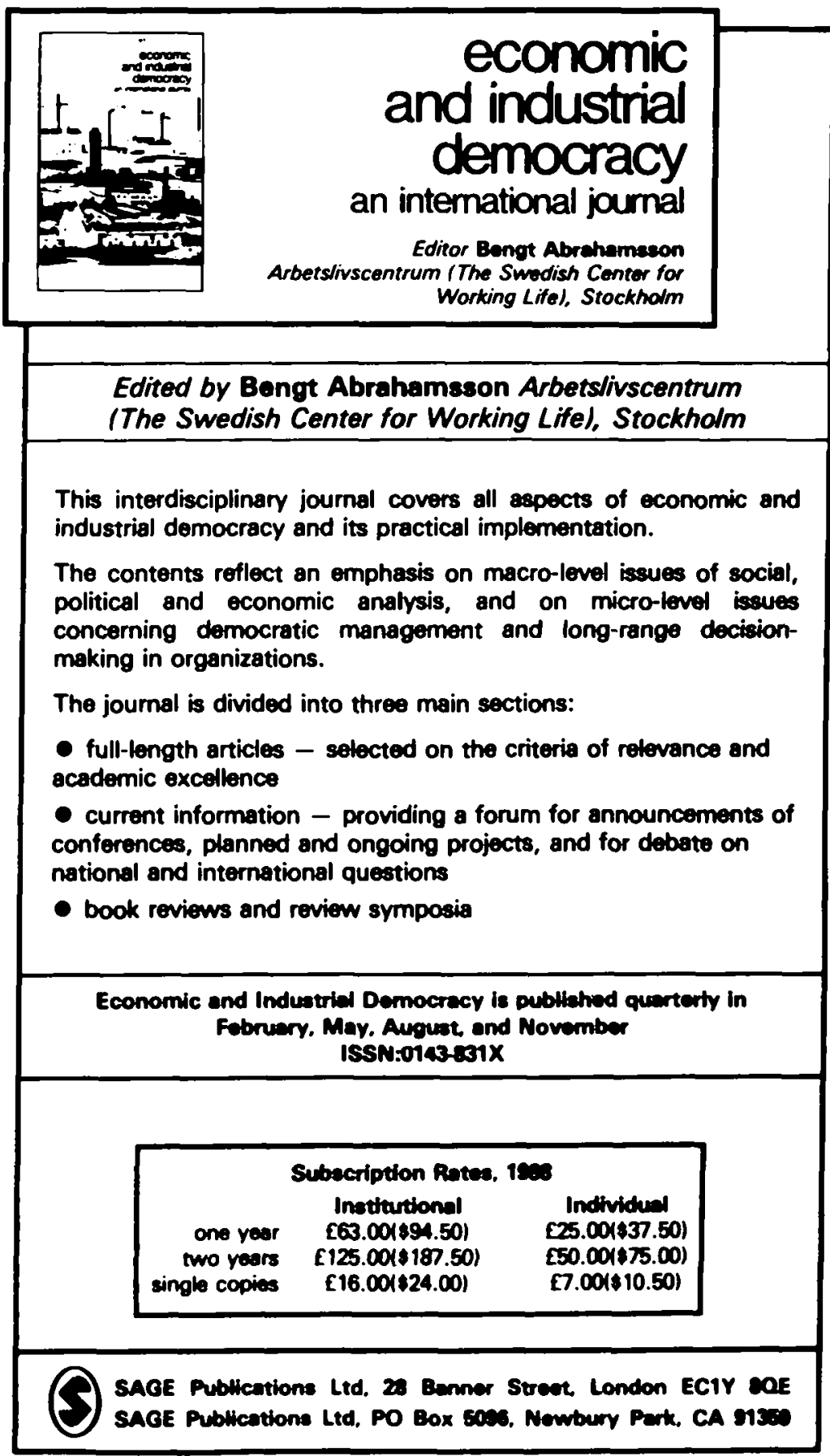

